University of Rhode Island

DigitalCommons@URI

Open Access Dissertations

1991

\title{
FACTORS INFLUENCING SELF-DISCLOSURE PATTERNS OF BLACK COLLEGE STUDENTS
}

Stanley Gene Cosby

University of Rhode Island

Follow this and additional works at: https://digitalcommons.uri.edu/oa_diss

\section{Recommended Citation}

Cosby, Stanley Gene, "FACTORS INFLUENCING SELF-DISCLOSURE PATTERNS OF BLACK COLLEGE STUDENTS" (1991). Open Access Dissertations. Paper 1010.

https://digitalcommons.uri.edu/oa_diss/1010

This Dissertation is brought to you for free and open access by DigitalCommons@URI. It has been accepted for inclusion in Open Access Dissertations by an authorized administrator of DigitalCommons@URI. For more information, please contact digitalcommons-group@uri.edu. 


\section{BFis \\ $\angle 67=$ \\ 199}

FACTORS INFLUENCING SELF-DISCLOSURE PATTERNS

OF BLACK COLLEGE STUDENTS

BY

STANLEY GENE COSBY

A DISSERTATION SUBMITTED IN PARTIAL FULFILLMENT OF THE REQUIREMENTS FOR THE DEGREE OF

DOCTOR OF PHILOSOPHY

IN

PSYCHOLOGY

26868912

UNIVERSTTY OF RHODE ISLAND

1991 


\section{ABSTRACT}

An experiment was performed to assess how gender, college environment, examiner's race, examiner's gender, target person's race (disclosure recipient), and target person's gender influence self-disclosure. These six factors were investigated by having the participants rate their degree of willingness to self-disclose to a Black male target person, Black female target person, White male target person, or White female target person. Jourard's Self-Disclosure Questionnaire was used. It is composed of six topic areas: Attitudes, Taste, Personality, Work, Money, and Body. The subjects consisted of 240 Black (120 male and 120 female) undergraduate students. One hundred twenty of the students attended a predominantly Black college and 120 attended a predominantly White college in the District of Columbia.

Several predictions were made. Predictions concerning race were that: Students on a predominantly Black campus will disclose more than students on a predominantly White campus; that students will disclose more in the presence of Black examiners than in the presence of White examiners, and that students will disclose more to Black target persons than to White target persons. Predictions concerning gender were that females will disclose more than males; that students will disclose more in the presence of female examiners than in the presence of male examiners; and that students will disclose more to female target persons than to male target persons.

A significant effect for target gender and target race was found. Subjects disclosed more when the target person was female than when the target person was male, and subjects disclosed more to a Black target person than to a White target person. No significant effects were obtained for subjects' school, examiners' race, subjects' gender, or examiners' gender. For topics of self-disclosure, subjects disclosed more to female targets persons than to male target persons on topics of attitudes, taste, 
personality, and body. Subjects also disclosed more to Black target persons in all topic areas.

An important implication that we may draw from this study is that Black students report more willingness to disclose more to female target persons and to Black target persons. These considerations should be taken into account in intra-racial counseling. 


\section{ACKNOWLEDGEMENTS}

I would like to express my sincere gratitude to several people who have assisted me in the completion of this research. Special thanks are extended to Dr. Albert Lott, my major professor, for his assistance in the design and completion of this research. Further appreciation is extended to the remaining members of my committee: Dr. Alice Brown-Collins, Dr. Paul Florin, and Dr. James Starkey.

I would also like to thank Dr. Joseph Rossi, Dr. Edward Carney, Dr. Edward Guadanoli, and Dr. John Houlihan for assisting me with the statistical analyses. I would also like to thank Dr. Gordon Dash for his inspiration. I would also like to thank my family who have supported me in completing this project. I also extend my thanks to Mrs. Gwen Davis who provided word processing services for this project. 


\section{CONTENTS}

I. Introduction 1

$\begin{array}{ll}\text { Purpose of the Study } & 2\end{array}$

Review of Literature 3

Reports on the Reliability and Validity of the

$\begin{array}{lll}\text { Self-Disclosure Questionnaire } & 6\end{array}$

Race and Self-Disclosure $\quad 7$

Gender and Self Disclosure 11

Implications for Black Students' Self-Disclosure in

Predominantly Black Colleges Versus

$\begin{array}{ll}\text { Predominantly White Colleges } & 14\end{array}$

$\begin{array}{lll}\text { Predictions Concerning Race } & 20\end{array}$

$\begin{array}{ll}\text { Predictions Concerning Gender } & 20\end{array}$

$\begin{array}{ll}\text { Predictions of Interactions } & 20\end{array}$

II. Method 22

$\begin{array}{ll}\text { Subjects } & 22\end{array}$

$\begin{array}{ll}\text { Instruments and Procedures } & 23\end{array}$

$\begin{array}{lll}\text { Self-Disclosure Questionnaire } & 24\end{array}$

$\begin{array}{llll}\text { Self-Disclosure Questionnaire Instructions } & 24\end{array}$

$\begin{array}{ll}\text { Personal Inventory Questionnaire } & 25\end{array}$

$\begin{array}{ll}\text { Analysis } & 26\end{array}$

$\begin{array}{llr}\text { III. Results } & 28\end{array}$

$\begin{array}{lll}\text { Total Self-Disclosure } & 28\end{array}$

Self-Disclosure Sub-Scales $\quad 39$

$\begin{array}{ll}\text { IV. Discussion } & 47\end{array}$

Implications and Future Research Directions 50 
$\begin{array}{llll}\text { Appendix } & \text { A } & \text { Questionnaire } & 51\end{array}$

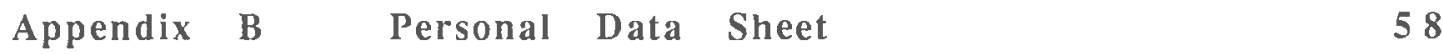

$\begin{array}{llll}\text { Appendix } & C & \text { Informed Consent } & 60\end{array}$

Appendix D ANOVA Summary on Attitudes and Opinions 61

Appendix E ANOVA Summary on Tastes and Interests 63

Appendix F ANOVA Summary on Work or Studies 65

$\begin{array}{llllll}\text { Appendix } & \text { ANOVA Summary on Money Subscales } & 67\end{array}$

Appendix H ANOVA Summary on Personality Subscale 69

$\begin{array}{llllll}\text { Appendix I } & \text { ANOVA Summary on Body Subscale } & 71\end{array}$

$\begin{array}{ll}\text { References } & 73\end{array}$ 


\section{LIST OF TABLES}

Table

1 ANOVA Summary of Total Self-Disclosure by

Subject College, Subject Gender, Examiner

Gender, Examiner Race, Target Gender, and

Target Race

2 Means and Standard Deviation on Total

Self-Disclosure by Target Gender

3 Means and Standard Deviation on Total

Self-Disclosure by Target Race

4 Means and Standard Deviation on Total

Self-Disclosure by Subject Gender and

Target Gender

5 Means and Standard Deviation of Total

Self-Disclosure by Target Race, Examiner

Race and Examiner Gender

6 Means and Standard Deviation on Total

Self-Disclosure by Target Gender, Target

Race and Subject Gender

7 Summary of Multivariate and Univariate

ANOVAS on Self-Disclosure Subscales by

Subject College, Subject Gender, Examiner

Gender, Examiner Race, Target Gender, and

Target Race

8 Means and Standard Deviation on Self-Disclosure

Subscales by Targel Race

9 Means and Standard Deviation on Self-Disclosure

Subscales by Target Gender

10 Means and Standard Deviation on Self-Disclosure Subscales by Target Gender and Subject Gender

11 Means and Standard Deviation on Self-Disclosure Subscales by Target Race and Examiner Race

12 Means on Self-Disclosure Subscales by Target

Race and Target Gender 


\section{CHAPTER I}

Introduction

Although Karen Horney (1950) developed an extensive theoretical account of people's inability to disclose themselves to others, it was Sidney Jourard (1958) who operationalized the construct of self-disclosure. He believed that authenticity and self-disclosure are important components of maturity. Jourard experimentally studied self-disclosure behavior by developing a sixty-item questionnaire, the most frequently used measure of self-disclosure. Several researchers later evaluated this questionnaire for validity and reliability and found it satisfactory.

Self-disclosure research has been an area that investigators have used to explore problems that are unique to counseling situations in which the interactants are ethnically varied. Although the findings have been promising, the number of studies is sparse. This is particularly true of research on the relationship between gender and ethnicity and selfdisclosure (Cosby, 1983; Dimont \& Hellkamp, 1969; Franco, Malloy, \& Gonzales, 1984; Levine, 1981; Jourard, et.al., 1958; Jourard, 1971). These studies have been concerned with consistent findings suggesting that minorities (Blacks, Hispanics, and Japanese) disclose less about themselves than their White counterparts. Several researchers feel that these trends can be explained and better understood by looking at examiner variables (Franco, Malloy, \& Gonzalez, 1984; Levine, 1981). Both of these studies investigated the self-disclosure patterns of Hispanics by varying the gender and ethnicity of the examiner. They found that the previous trend of low self-disclosure of Hispanics was not maintained. Analysis of total selfdisclosure scores revealed that females disclosed more than males, and Hispanics disclosed less than Caucasians. However, when the gender and ethnicity of the examiner were varied, this trend disappeared. Under certain conditions (i.e., with a Hispanic female examiner), Hispanics 
reported self-disclosure comparable to or surpassing self-disclosure reported by White Americans. Of particular relevance is the fact that when the administrator was a Hispanic female, the Hispanic male students selfdisclosed to a significantly greater degree than with any other examiner. This examiner effect may be true for other minorities.

\section{Purpose of the Study}

The purpose of this study was to determine the preferences of Black college undergraduates for Black and White counselors from the extent to which they were willing to self-disclose, as measured by Jourard's SelfDisclosure Questionnaire (revised) to each of four target persons: Black male, age 30; Black female, age 30; White male, age 30; White female, age 30.

The study sought further to determine if the differences in the extent to which students were willing to self-disclose were related to their schools' racial environment, as indicated by the students' enrollment at either a predominantly Black university or a predominantly White university. Additionally, all subjects' responses were examined for differences in their willingness to self-disclose to target persons when the examiners' race and gender were varied. It was conceivable that amounts of disclosure to target persons would vary, and that disclosure to target persons would be influenced by the race and gender of those who administered the Jourard Self-Disclosure Questionnaire. Both Black and White male and female examiners administered the questionnaire.

Therefore, in determining counselor preference of the students, the study sought to determine if Black students were more willing to self-disclose to Black male and female target persons than to White male and female target persons.

In addition, categories of information on Attitudes and Opinions, Tastes and Interests, Work or Studies, Money, Personality, and Body were included as content for disclosure to target-persons. The study sought to 
determine if students differed significantly in the categories of information they were willing to disclose to Black and White targetpersons, and to which target-person was the most personal information disclosed.

\section{Review of the Literature}

The early characterological studies of Karen Horney (1950) were some of the first to draw attention to what she called the alienated individual. She characterized the problem of alienation as a common tendency among adults to misrepresent themselves to others. Such individuals have a need to evolve artificial and strategic ways to cope with others by disguising their genuine feelings, wishes, and thoughts. The real self, she asserts, is the "unique, alive, personal center of ourselves: the part that wants to grow" (Horney, 1950). She feels that alienated individuals are characterized as having lost the feeling of being an active determining force in their own lives: they are alienated from the most alive center of self which she calls the real self.

Her theories propose that self-alienated individuals are astute observers of others and their world, yet they tend to block out certain feelings and thoughts of their own. The self-alienated individual may, for example, talk about his or her experiences in a depersonalized fashion. $\mathrm{He}$ talks about himself without "being in it, or he may sleep with a woman without being in it." (p. 161) Such individuals appear to be driven by compulsive forces as opposed to being the driver in control of themselves. This type of individual's behavior results in active moves away from the self.

Jourard (1968) has studied the behavior of moving away from the real self in a direct way by experimentally investigating self-disclosure behavior. He hypothesized that the accurate portrayal of the self to others is an identifying criterion of a healthy personality, while neurosis is 
related to an inability to disclose one's real self to others. $\mathrm{He}$ argued that "authentic being" requires courage and "involves the act of being one's real self honestly in one's roles, as well as in one's relations with other human beings." (Jourard, 1971, p 41.) It demands behaving in ways essentially the opposite from the self-alienated individual, because such behavior aims to drop pretense and duplicity.

However, humans seem obliged to hide much of their real selves from themselves and others. Jourard feels that self-disclosure is a means of ultimately achieving a healthy personality. Until a person begins to seek out and develop his real self, Jourard feels that he had not begun to mature. One's self, he argues, "grows from the encounter of others as well as from the experiences of living." (p. 125) People come to need help, he further argues, because they have not disclosed themselves to some degree to the significant other people in their lives. Disclosure thus gives a person a chance to free associate all of his anxiety provoking thoughts and feelings which he would not dare to readily disclose to himself, much less to another. A key characteristic of a healthy personality, self-disclosure results in growth and well-being.

In order to study self-disclosure, Jourard initially drew up a set of 100 questions about the kinds of things one asks another person if one wishes to know him or her personally. He began by asking his colleagues how many of the questions did they think their wife and closest friend could answer. Jourard (1958) refined his first list of questions, and produced a questionnaire listing sixty topics of a personal nature that were classified into six categories, or aspects of self. This instrument was named the "Self-Disclosure Questionnaire."

The Self-Disclosure Questionnaire is composed of sixty items which are rated on a zero to two point scale for amount of disclosure. Zero is no disclosure, a score of one means that the person will disclose a little about themselves on this item, and a score of two means that the person will 
disclose fully about how they feel on this item. The items are classified in groups of ten within each of six more general categories of information about the self (aspects). The more general categories of information are Attitudes and Opinions, Tastes and Interests, Work (or Studies), Money, Personality, and Body. The content of information on Attitudes and Opinions includes items on religion, politics, morality, and personal standards of beauty. Examples of questions asked in this topic area are "my views on communism", "my feelings about how parents ought to deal with children", and "my personal opinions and feelings about other religious groups than my own, e.g., Protestants, Catholics, Jews, Athetists."

Likes and dislikes in food and beverages, music, reading, clothing and leisure activities are among the items included under information on Tastes and Interests. Examples of questions asked in this topic area are "my likes and dislikes in music", "what I would appreciate most for a present", and "my favorite ways of spending spare time, e.g., hunting, reading, cards, parties, sports events, dancing, etc. Work (or Studies) includes items on feelings and aspirations about work or studies, e.g. "what I feel are my shortcomings and handicaps that prevent me from getting further ahead in my work", and "what I find to be the worst pressures and strains in my work". Items on financial worth and need are included in the content of information on Money. Examples of questions asked in this topic area were "whether or not I had savings, and the amount", "whether or not I gambled. If so, the way I gamble and the extent of it".

Under Personality, concerns about temperament, pride, guilt, and sexual behavior are included as content items. Examples of questions asked in this topic area were "what feelings, if any, that I have trouble expressing or controlling", and "the kind of things that just make me furious".

Finally, feelings and concerns about physical characteristics and health are among the items on information about Body. Examples of questions in this topic area are "how I wish I looked; my ideas for overall 
appearance", and "my feelings about different parts of my body - legs, hips, waist, height, chest, or bust, etc."

In an attempt to determine if the Self-Disclosure Questionnaire does measure the amount of personal information one individual disclosed to another, and to increase the range of responses, Panyard (1973) revised the Self-Disclosure Questionnaire by allowing subjects to rate themselves on a one to six point scale for amount of personal information disclosed, instead of the original rating scale of zero, one, or two. She found that the scale was valid for measuring the amount of personal information exchanged between the friends she studied, and concluded that the Self-Disclosure Questionnaire is a valid measure of self-disclosure to a specific target person, that it does, in fact, measure what it claims to measure.

Instructions for completing the Self Disclosure Questionnaire were altered in the present study to reflect the subjects' willingness to disclose to four target persons. Target persons were altered to reflect racial identity, sex, and age of each person. The assigned age for each target person was thirty years, the age to which it was found that Black college students were most likely to self-disclose (Jackson, et. al., 1973). Mother, father, and friends are eliminated as target persons. They are replaced by sex, race, and age descriptions of four target-persons: Black male, age 30; White male, age 30; Black female, age 30; and White female, age 30 , to whom information about subjects was communicated. (See Appendix A for the questionnaire).

\section{Reports on the Reliability and Validity of the Self-Disclosure Questionnaire}

Reliability studies by Jourard and Lasakow (1958) using the split-half estimate produced an alpha coefficient of .94 , with correction, in their 
initial study indicating that the subjects responded consistently to the questionnaire over all target-persons and all aspects of self.

Using odd-even split half correlations with a retest five months later, Panyard (1971) investigated the reliability of the Self-Disclosure Questionnaire. The alpha coefficient was $.93(n=80)$ with the retest reliability $.91 \quad(n=37)$. The construct validity of the Self-Disclosure Questionnaire was also investigated by Panyard who asked twenty-six pairs of friends to indicate the amount of personal information disclosed to and received from them. She found consensual validation in the amount of personal information exchanged and concluded that the Self-Disclosure Questionnaire is a valid measure of self-disclosure to a specific target person.

Himelstein and Lubin (1965) attempted validation of the SelfDisclosure Questionnaire by the peer nomination technique. Fraternity and sorority groups were asked to make peer nominations for "most likely to confide in others" and for "most likely to tell my troubles to." Split-half reliability for the inventory was .82 , after correction for the SpearmanBrown formula. Jourard (1961) reported that productivity on the group Rorschach correlated .37 ( $p<.05)$ with a total score of the Self-Disclosure Questionnaire, and interpreted the finding as being supportive of the validity of the instrument.

\section{Race and Self-Disclosure}

Research on race and self-disclosure has been concerned with two rather consistent trends. One suggests that Blacks disclose less about themselves than Whites. The second trend suggests that when given a choice, Black clients prefer racially similar counselors. A few researchers, however, reported some divergent patterns. This section will review these areas of research.

Jourard was one of the first examiners to study racial differences in self-disclosure patterns (Jourard, et.al,1958). He evaluated a large pool of 
subjects and within this pool, he selected a subset of White and Black male and female students. He had the subjects tested by an examiner of the same race and found that the four groups differed in total self-disclosure. White subjects disclosed more than Black subjects and the females disclosed more than the males. The subjects also varied in the amount of selfdisclosure to specific target persons. For example, he found that Black male subjects consistently disclosed less about themselves to father as a target person, than to mother, male friend and female friend.

A study by Cosby (1983) is slightly divergent from other studies of race and self-disclosure. This examiner looked at race, gender and socioeconomic status of college students. No significant difference was found in amounts of the willingness to self-disclose of Black and White college students, and no significant difference was found in amounts of the willingness to self-disclose of upper and lower socioeconomic statused students. Differences were found for gender in that Black females report more willingess to self-disclose than Black males. Self-disclosure to various target persons also varied. Black females report more willingness to self-disclose to Black female target persons than to Black male, White male, and White female targets. Black males also reported more willingness to self-disclose to various target persons in the following order: Black female, White female, Black male, and White male.

Another line of research on Blacks and Whites and self-disclosure has investigated the preference of clients for racially similar versus racially different counselors. Most of the research has found that Black subjects tend to prefer racially similar counselors. A study by Pinchot, Ricco and Peters (1975) evaluated Black and White elementary school children and their parents' preference for racially similar counselors. Subjects viewed a video tape of six counselors' interviews with six racially different counselors interviewing the same student. They found that Black and White students preferred counselors of their own race. A similar study was done 
using Black and White high school students (Riccio \& Barnes, 1973). They found that White students did not prefer White counselors over Black counselors.

Wolkon, Moriwaki and Williams (1973) studied college students' preferences for racially similar counselors. They administered a questionnaire to students to ascertain preferences for a racially similar versus a racially different counselor. A significant percentage of Black and White students preferred racially similar counselors. In another study of Black college students at a predominantly White college, Jackson (1975) found that 94 percent of the students preferred a Black counselor.

In a similar study, Jackson and Kirschner (1973) examined the preferences of Black college students for racially similar counselors by measuring the students' sense of cultural identity. Subjects were given a questionnaire which asked them to designate what they considered to be ideal characteristics of counselors, and to list their preference for a counselor's race. Students were also asked to list how they preferred to be referred to as Black, Negro, Afro-American, or Colored. They found that students who stated that they were Black or Afro-American preferred Black counselors to a more significant degree than did those who regarded themselves as Negro. The few subjects who identified themselves as Colored were excluded due to the paucity of subjects. The authors posit that racial identity is reflected in how Blacks prefer to be referred to, and is a significant factor in preference for counselor of the same race.

Singleton (1978) looked at both Black college students' cultural/racial identity and the impact it has on students' preferences for racially similar versus racially different counselors. She evaluated Black college students' preferences by having them rate how willing they were to self-disclose to each of four target persons: Black male, Black female, White male, and White female, as measured by Jourard's self-disclosure questionnaire. She measured their racial sub-group identification by asking students to select 
their preferred racial titles from these categories: Afro-American, Black, Colored, or Negro. Lastly, she sought to determine if Black students differed in the extent to which they were willing to disclose categories of personal information on attitudes and opinions, tastes and interests, work or studies, money, personality and body, and to which target person was the most personal information disclosed. She found that subjects would be willing to self-disclose to Black target persons to a significantly greater extent than they would to White target persons. They were willing to selfdisclose significantly more personal information on money, personality, and body to Black target persons than they did to White target persons. She also found that subjects were more willing to disclose significantly more personal information on attitudes, and taste and work, than on money, personality, and body. Lastly, she found that there was no significant difference in the willingness of students to self-disclose regardless of identification as Afro-American, Black, Colored, or Negro.

On the other hand, another group of studies did not find a consistent pattern of Blacks disclosing less about themselves than Whites, or of Blacks preferring racially similar counselors (Backner, 1976; Briley, 1977; Cosby, 1983). A study by this author looked at race, gender and socioeconomic status of Black college students and found no significant difference in amounts of total self-disclosure of Black and White college students. Differences were found for gender with females self-disclosing more than males and for self-disclosing to various target persons. Also, Black females reported more willingness to self-disclose to a Black female target person than to a Black male, White male and White female targets.

Backner (1976) surveyed 174 Black college students in order to determine their preference for the same race counselor. She asked the subjects to fill out a questionnaire which asked them to list if whether or not a hypothetical counselor's racial background should be the same as theirs or different from theirs. She found that 25.3 percent of the students 
stated that the counselor's race should be similar to the counselee's, while 68.4 percent stated that it did not matter if the counselor's race is different from theirs. A similar study by Briley (1977) measured counselor preferences of Black college students at different universities. He gave a counselor preference questionnaire to 640 Black college students and found that the majority of Black females expressed no preferences for counselor's race or counselor's sex. On the other hand, he found that some Black males expressed a preference for a counselor of the same race. He argued that this study suggests that Blacks are not a homogenous group when it comes to selecting a counselor, and that the study of counselor preference across racial lines is a complex issue which is influenced by multi-dimensional factors.

Thus, research on race and self-disclosure clearly demonstrates the need to examine this factor whenever race differences in disclosure are examined. However, the findings on racial differences in self-disclosure rates and in counselor racial preference have been mixed. More research needs to be done in order to accurately examine this complex variable. In the next section, another layer of complexity will be superimposed on race, that of gender. The next section will examine the impact that gender has on mediating self-disclosure.

\section{Gender and Self-Disclosure}

Research on gender and self-disclosure has focused on the role that sex role attitudes and situational,factors play in mediating gender difference in self-disclosure. Sex role attitude studies have focused on examining the differences in self-disclosure of male and females, and in examining the pattern of opposite sex and same sex disclosure. Research on the role that situational factors play has focused on topics of disclosure, sex of target (disclosure recipient), and relationship to target. / How these variables impact on self-disclosure patterns will be discussed in this section. 
The findings on sex role attitudes have been mixed, some showing females disclosing more than males, and others showing no significant differences. Jourard (1971) found that females disclosed more than males. He also found that differences exist between opposite sex and same sex disclosure. Female to female disclosure being highest, and male to male disclosure being lowest.

A study by this author (1983) of Black and White college students found that there was a significant difference in reported rates of selfdisclosure by sex, with females disclosing more than males, but no difference by race or socioeconomic status. The finding of significant gender differences is consistent with several of Jourard's studies (1958, 1971). He argues that the pattern of female disclosing more than males is a result of sex role attitudes which result from the socialization process. $\mathrm{He}$ posits that men have been socialized to dread being completely open to others and as a result, are continually more tense and less empathic than women. A man's sex role, he states, "requires him to appear tough, objective, and generally emotionally unexpressive." (Jourard, 1968, p. 35). The adult male, he argues, is unwilling to disclose certain aspects of himself for fear that this will be regarded as a sign of weakness. Weeping in public or private, for example, would probably cause others to perceive him as weak and inferior to other men. Men are also less likely than women to disclose their sickness to others, or to consult a doctor until their illness has become so aggravated that it can not be ignored. Jourard states that man is thus non-disclosing "because other people might pry open his secrets in an unguarded self-disclosing moment, and reveal his true self in its nakedness, thereby exposing his area of vulnerability." (Jourard, 1968, p. 35)

Although several authors have found consistent differences between self-disclosure rates of males and females, with females self-disclosing more than males, other authors have found divergent results (Singleton, 
1976; Rubin, 1978). Singleton (1976), for example, did not find any sex differences in self-disclosure among Black college students to various self-disclosure targets. Another researcher who examined the sex role attitude behaviors of dating couples also discovered divergent results. Working on the premise that traditional sex role attitudes inhibit men's disclosure but not women's, Rubin and Stall (1981) reasoned that sex role attitudes should affect disclosure in male-male friendships, but not in female-female friendships. They found that men's disclosure was less than women's disclosure regardless of sex role attitudes. He explained this finding by suggesting that although the modern male's role is thought to emphasize interpersonal skills, the capacity for emotional intimacy is generally restricted to romantic heterosexual relationships and excluded elsewhere. It is acceptable for a modern male to open up to his girlfriend, but not to other men. Hence, sex role attitudes have an effect on disclosure in opposite sex dating relationships, but not in same sex friendships (Rubin, et. al.,1980).

Although these findings are significant, a major criticism of the results has been of the measures used to assess self-disclosure differences. Derlega (1987), for example, argues that most of the theory about gender differences in self-disclosure has focused on the inhibiting effects of male role prescriptions, yet the two major measures of sex role attitudes that have been used extensively in research have focused on female role prescriptions. The TRAD, a scale which measures sex role traditionalism, and the Attitudes Toward Women Scale have been used widely.

The other line of research in gender and self-disclosure has focused on the role that situational factors such as topics of disclosure, sex of target (disclosure recipient) and relationship to target play in mediating gender differences in self-disclosure. Researchers have found that sex differences in self-disclosure are often a function of disclosure topic. 
Kamorovsky (1967) found that women tend to disclose more personal information about themselves than men. Women disclosed more information about their home, and relationships with family and friends. They also disclosed more about feelings, things they were afraid of and accomplishments at school or work. Men, on the other hand, disclosed more about cars, sports, work, politics, and business. Men also disclosed more information about things that they were proud of (Hill, Peplau, \& Rubin, 1981). Here again, researchers have explained these findings by noting that traditional sex role expectations encourage women to be concerned about socio-emotional matters. Men are socialized to be emotionally unexpressive; nonetheless, they are willing to disclose information about nonpersonal matters.

A finding which is divergent from traditional results was obtained by Singleton (1976). She did not find a gender difference in rates of selfdisclosure of intimate and non-intimate information of Black college students. It is difficult to explain why these differences exist due to the paucity of research on self-disclosure of Black college students.

Research on the situational factor (sex of target) have found differences between opposite sex and same sex disclosure (Brooks, 1974; Inman, 1978; Jourard, 1971). These researchers have found that both men and women disclosed more to a woman than to a man. Research by this author also found that Black students preferred to self-disclose to female targets rather than to male targets (Cosby, 1983).

Research on the target's relationship to the subject have found that subjects disclose to friends at a greater rate than to strangers (Chaikin \& Derlega, 1974; Jourard, 1971). Other researchers have found that social status influences self-disclosure in that disclosure tends to flow from those low in power to those high in power in organizational settings. However, this tendency has been found to be inconsistent when it comes to gender differences. Researchers have found that males disclose more to 
higher status organizational persons whereas females disclose more to low-status organizational personnel, indicating that effects of social status may be influenced by gender (Derlega, 1987).

Thus, research on sex role attitudes, ethnic identification of interactants, and situational factors influencing self-disclosure clearly demonstrates the need to take these factors into account whenever gender differences in disclosure are examined. Some researchers posit that the discrepancy in findings is a result of faulty measures. It is clear, however, that more research needs to be done in order to examine the multidimensionality of these variables. Another factor to consider is the impact of racially diverse college environments on the self-disclosure process of Black college students.

\section{Implications for Black Students' Self-Disclosure in Predominantly Black Colleges Versus Predominantly White Colleges}

Several authors point out that Black students do not do as well in predominantly White colleges as they do in predominantly Black colleges (Browning, 1978; Williams, 1978; Fleming, 1984; Thompson, 1978). These authors posit that the reason for this is rooted in the history and tradition of both college environments.

Several forces impacted on the development of Black colleges. Many of these colleges developed after Lincoln's Emancipation Proclamation of 1863. The American Missionary Association took the first major steps towards educating freed men and women and founded seven Black colleges between 1861 and 1870, although the missionaries were often discouraged because the laws in the South prohibited Blacks from being taught how to read and write, they persisted. The Plessy v. Ferguson Supreme Court Decision in 1896 made it possible to set up separate public institutions for 
Blacks and Whites. In addition, the Gung Lum v. Rice decision of 1927, allowed racial separation to be extended to include public and private educational institutions. The effect of both Supreme Court decisions was the sanctioned denial of access to White colleges for the overwhelming majority of Blacks.

Religious, economic, and philosophical issues also impacted on the development of the Black college. Like mainstream colleges, many of the original historical Black colleges founded by missionaries were interested in training clergy and teachers in order to assist in the transition from slave to freed person. Toward the turn of the century, the issue centered on the W.E.B. Dubois-Booker T. Washington debate. Dubois advocated developing a well-rounded, liberal arts educated freedman. On the other hand, Washington saw the golden opportunity in the fields of industry, agriculture and technology. There has also never been a time in the history of Black colleges that they were not faced with financial crisis, and were not working with more than a shoe string budget (Fleming, 1984). Despite these difficulties between 1870 and 1950, more than 147 Black colleges were founded.

After desegregation, many authors argued that it was the attitude of Black college professors that made a difference in keeping the colleges going and in educating Black students (Mays, 1971; Fleming, 1984). The sense of being on a mission to produce educated leaders for Black people to uplift the race was prevalent among many Black faculty. From the beginning and through the present day, this was an awesome feat in light of the fact that 90 to 95 percent of the Black adult population was functionally illiterate in the first few years after emancipation.

Although numerous forces shaped the founding, development and philosophy of Black colleges, an essential variable which helped to shape Black colleges was the devotion of a few Black faculty members who stayed at the Black colleges although better money offers were made by 
predominantly White colleges. For example, Mays (1971) notes of Morehouse College that even though salaries were low, devotion was high and the faculty "made Negro students believe that they could do big and worthwhile things." In addition, the faculty-student interaction at Black colleges was unique. Teachers at the Black colleges, regardless of their own racial or ethnic identity, are expected to have knowledge of the history and culture of Black Americans and be able to integrate relevant concepts of the Black experience into their particular academic discipline (Thompson, 1978). The social backgrounds of many Black teachers in Black colleges are also similar to those of their students. Many of them identify with the Blacks' struggle for advancement and most of them sacrificed a great deal in order to become accomplished in their field. Not only are the faculty members held in high esteem by the students, but also by the Black community. In fact, there is reason to believe that Black college teachers enjoy a somewhat higher social status among their students than do comparable White teachers, because teachers in all prestigious White colleges are likely to have students whose parents and relatives are of higher status than their own. This is rarely the case in a Black college. Not only do Black faculty members generally earn higher income than the overwhelming majority of their students' parents, but many Black faculty members are also influential local and national leaders. This relatively high status affects the nature of the teacher-student interaction in that this is one of the key ways that Black students learn middle class ways and manners. Role modeling for disadvantaged Black youth is often seen as a primary role of teaching and many take the task of preparing them for making it in a White-dominated, middle-class environment very seriously. It is this type of sustained personal contact with teachers as well as an accepting sociopolitical climate which lead many Black students to state that these are the "personal" reasons why they choose Black colleges over White institutions (Fleming, 1984). 
Black students who attended college in the 1960 s have only recently been allowed to attend White colleges in significant numbers. Over half of those registered in predominantly White institutions attended two year colleges. Many students in these institutions were there by virtue of recruitment efforts that began on a large scale in the 1960s. Although many Black students adapted to the White college environment and were excited by the opportunity to get an education in an integrated setting, there were many who expressed considerable dissatisfaction with their experience.

A series of large scale studies which looked at the interpersonal and intellectual/occupational development of Black college students at both Black and White colleges were done by Fleming (1984). In one of these studies, she examined the attitudes of Black college students at eight predominantly White, and seven predominantly Black institutions. She analyzed the difference in the general functioning level between students in Black and White colleges in a cross-sectional study by looking at the differences between freshmen and seniors in Black and White colleges. Fleming explained her findings in terms of "patterns or pictures of students' experiences at each school." She then compared these schools to each other.

On the whole, she found that the intellectual development of Black students in White colleges was impoverished and that this was largely due to their inability to develop strong interpersonal/mentoring relationships with faculty members. She also found that a hostile environment existed on many predominantly White college campuses, which caused defensive reactions in the Black students. She posits that these dynamics interfere with their intellectual performance and interpersonal development, and by inference, their self-disclosing behavior. She noted that the Black students in the seven predominantly Black campuses found expressions for their power and personal motivations, and that they came to enjoy competition. On predominantly White campuses, she discovered that Black students often 
did not find expression for their power and personal motivations, and they often felt sub-dominant. She also discovered that this situation hit the male the hardest, and the problem was largely an interpersonal one. This is the key variable that differentiated Black students' experiences on predominantly White college campuses as compared to predominantly Black college campuses. This interpersonal variable, in many cases, was the cause of their inability to form cooperative relationships, or it caused the Black male to withdraw academically and psychologically. She found that Black women in predominantly White colleges suffer from emotional pain, social isolation, and fear of their competence. These problems are not experienced by Black students at predominantly Black colleges. It is Fleming's contention that more research exploring these and other variables need to be done so that we can isolate the interpersonal variables that inhibits students' maximal development.

Although the relationships between the college environment and selfdisclosure patterns of Black college students has not been investigated, the relationship between self-disclosure and success in college by majority culture students was studied by Jourard (1973). He examined 170 nursing students and divided them into high and low self-disclosers as measured by Jourard's Self-Disclosure Questionnaire. He found that high disclosing students had significantly higher grade point averages than lower disclosers, and that higher disclosers were better adjusted to college life. Jacqueline Fleming (Personal Communication, January 9, 1986) pointed out that the ability to self-disclose appropriately in interpersonal relationships between students and professors is largely equated with intelligence and that constructive cooperative relationships are the essence of intellectual development.

Thus, the presence of a significant number of highly established, devoted Black teachers, the teaching from a Black perspective by both Black and White teachers at Black colleges, and importantly, an emotionally 
supportive environment whereby Black identity issues can be worked through all suggest that the Black college environment may be a better place than White colleges for Black students to exhibit maximal selfdisclosing behavior, particularly self-disclosure to appropriate authority figures. The impact that the environment of predominantly White colleges and predominantly Black colleges has on the self-disclosure behavior of Black college students was explored in this study. Thus, each of these variables (racial environment on campus, examiner's race and gender differences, target persons' race and gender, and subjects' gender differences) will be investigated.

To sum up, the research on self-disclosure has examined a wide range of variables such as race, gender, relationships, socioeconomic status, and choice of counselor. Although there are many areas that are being studied, this research will examine the self-disclosure patterns of Black college students because the research is extremely limited. The past research in this area has focused on documenting differences between Blacks and Whites, and how race impacts on counselor preferences (Jourard, 1971; Singleton, 1976). This current investigation adds to our knowledge base of self-disclosure patterns of Black college students by looking at environmental and examiner effects. These two variables have not been examined together in any previous studies. The Jourard Self-Disclosure Questionnaire was selected because this researcher is solely interested in documenting the patterns of self-disclosure behavior of Black college students.

\section{PREDICTIONS}

The predictions relative to self-disclosure were as follows:

\section{Predictions Concerning Race}

1. Total self-disclosure will be influenced by the racial environment on campus. That is, the Black students on a predominantly Black campus 
will be willing to disclose more than Black students on a predominantly White campus.

2. Total self-disclosure by Black college students will be influenced by the race of the examiner. That is, they will be willing to disclose more in the presence of Black examiners than in the presence of White examiners.

3. Total self-disclosure by Black college students will be influenced by the race of the target person. That is, they will be willing to disclose more to Black target persons than to White target persons.

\section{Predictions Concerning Gender}

4. Total self-disclosure of Black college students will be influenced by gender. That is, females will be willing to disclose more than males.

5. Total self-disclosure by Black college students will be influenced by the gender of the examiner. That is, they will be willing to disclose more in the presence of female examiners than in the presence of male examiners.

6. Total self-disclosure by Black college students will be influenced by the gender of the target person. That is, they will be willing to disclose more to female target persons than to male target persons.

\section{Predictions of Interactions}

In addition to the above predictions, the interactions among the major variables (subject's gender, examiner's race and gender, target person's race and gender, and campus racial environment differences) will be determined, although no specific predictions are being offered. While it is possible to make more predictive statements about interactions between main variables based on findings of past studies, I would rather explore these predictions in aposteriori follow-up tests. This method is appropriate because the past studies which made predictions (Jourard, et. al.,1958; Jourard, 1971; Singleton, 1976) were conducted many years ago. The current information on the amount of disclosure to specific target persons 
is not extensive enough for making predictions about the targets of self disclosure. The interaction of the topics of self-disclosure with the major variables will also be examined. Again, no specific predictions are being offered for the aforementioned reasons. The present investigation will, therefore, document the findings without making specific predictions about the amount of self-disclosure to specific target persons. 


\section{CHAPTER II \\ METHOD}

\section{Subjects}

The subjects of the study were limited to American-born, Black college students enrolled in two universities in the Washington, D.C. area during the 1986-1987 academic year. The subjects consisted of 240 Black (120 male and 120 female) undergraduate students. One hundred and twenty of the students attended a predominantly Black college and 120 students attended a predominantly White college in the District of Columbia. No information was gathered concerning why the subjects chose to go to a predominantly Black college as opposed to a predominantly White college. Students were equally selected from all four years in college (30 freshmen, 30 sophomores, 30 juniors, and 30 seniors from both Black and White colleges). For the predominantly Black college, the mean age was 24.0 years, standard deviation, 1.50, with a range of 17-28 years. The mean age for students attending a predominantly White college was 20.0 years, standard deviation, 1.0, with a range of 17-25 years.

The majority of students from both colleges came from lower middle and middle class backgrounds, as judged by parental education and occupation (see Personal Data Summary Sheet, Appendix B). From the Personal Data Summary sheet, it was determined that thirty-two percent of the sample had received counseling of a vocational/educational nature at least once; 68 percent had received no previous formal counseling. Seventyfive percent of the students had seen a Black counselor during their counseling experience(s); 25 percent had seen a White counselor. A Black female counselor would be the person to whom 47.9 percent of the sample would presently go for counseling; 37.1 percent to a Black male counselor; 3.3 percent to a White male counselor, 2.1 percent to a White female counselor and 9.6 percent to an "other" counselor. 


\section{Instruments and Procedures}

\section{Self-Disclosure Questionnaire}

All subjects were tested for their degree of self-disclosure to Black male, Black female, White male, and White female target persons. Selfdisclosure was measured by using the Self-Disclosure Questionnaire developed by Jourard. This questionnaire consisted of sixty self-revealing questions which subjects responded to in order to discover how much they were willing to disclose certain topics of information about themselves to certain other persons. Each participant responded to each question by selecting a rating of $1,2,3,4,5$, or 6 for each of the sixty items (see Appendix A).

A score of one means low self-disclosure and a score of six indicates a high degree of self-disclosure for that item. There are sixty items and six categories of information that subjects disclosed information about. They are: Attitudes and Opinions; Tastes and Interests; Work or Studies; Money; Personality; and Body. Since the questionnaire included 60 items and there are four target persons, a total of 240 entries are made by each subject. These entries for each category of information ranged from 1 to 6 . The means of the subscale or categories of information scores and the means of the total scores were used in several analyses. Thus, a mean score of 3 indicates low self-disclosure, while a mean score of 6 indicates high self-disclosure. The Jourard Self-Disclosure Questionnaire was designed as one continuous 60 -item scale with 6 subsections. These subsections or subscales have not been factor analyzed.

A Personal Inventory Questionnaire was also administered. This questionnaire was administered in order to clarify some of the results. This questionnaire elicited demographic and ethnographic information about a subject's family background, and their preferred racial identity, whether Afro-American, Colored, Negro, Black or Other. This questionnaire also 
elicited information about the subject's previous counseling history and their preference for a future counselor. This information is used to help interpret the findings.

\section{Self-Disclosure Questionnaire Instructions}

Immediately upon entering the experimental room, each subject was seated and given a packet containing a self-disclosure questionnaire, and a personal inventory questionnaire. The order of explanation involved explaining the self-disclosure questionnaire first, and then the personal inventory questionnaire. The following instructions were administered orally to each group of subjects:

The packet that you have been given contains two questionnaires, and they should be answered in the order that I am presenting them. There are two important things that I would like you to observe before you begin to fill out the questionnaires. First, please answer each question; do not omit any questions. I need your answers to all questions to make my study valid. Second, please answer each question honestly. I am interested in what you really think and feel. You do not have to put your name on these questionnaires, so please be totally honest with your answers to the items. Are there any questions? You may voluntarily withdraw from this study at any time. Please listen as I explain how to fill out the questionnaires. Please look at the first page of the first questionnaire and follow along as I read the directions. The first answer sheet in your packet is to the first questionnaire, which has columns with the headings "Black Male, age 30"; "White Male, age 30"; "Black Female, age 30"; and "White Female, age 30". You are to read each item on the questionnaire and then indicate on the answer sheet the degree to which you will let each of these several people know this information about you. Use the rating scale that you see on the 
answer sheet to describe the extent to which you will allow these persons to know the pertinent facts about yourself. In other words, how willing are you to give each of these four persons a complete, up-to-date, accurate picture of yourself as you are now. On this scale, the lowest rating of one (1) means that you would not let that person know you in this respect right now because you would lie or misrepresent yourself. The rating of two (2) means that you will disclose nothing about this aspect of yourself. The rating of three (3) means that you will talk very little about this area. A rating of four (4) means that you will talk in general terms about this aspect of yourself, of what is true in this respect, but his idea of you would not be complete or specific. A rating of five (5) means that you will disclose quite a bit about this area. A score of five (5) means that you would talk quite a bit about this item and that the person would have an informed idea about this aspect of you. Finally, the rating score of six (6) means that you will disclose fully on this topic.

Following this, the group of subjects were asked if they had any questions about how to fill out the questionnaire. The instructions were repeated and clarified for those who failed to indicate a clear understanding.

\section{Personal Inventory Questionnaire}

Subjects were also given the Personal Inventory Questionnaire developed by Singleton (1978) (Appendix B). This questionnaire consists of basic demographic and ethnographic information about the subjects' family backgrounds, and their preferred racial identity, whether Afro-American, Black, Colored, Negro, or Other. It asks questions about the subjects' year in college and questions about whether or not a person has been in counseling before.

It also asked questions about how long as well as what was the area of concern of the counseling. Lastly, the questionnaire asked each subject to 
select whom they would prefer to go to for counseling if they were to enter counseling from a list of counselors which included a choice of Black male, White male, Black female, White female, and Other.

The instructions for the Personal Inventory Questionnaire were worded in the following manner:

Below are listed a number of questions which pertain to your personal background. Please look at the first page of the Questionnaire and follow along as I read the directions. Thank you for your participation in this study. All information and responses on this questionnaire are confidential. Your answers will be used for statistical purposes; however, your name is not required. It will be very helpful if you would answer all items which apply to you. You are to read each question on the questionnaire and then indicate your answer to the personal data on the Questionnaire.. For example, in the appropriate space, check if you are male or female; list your age, and your

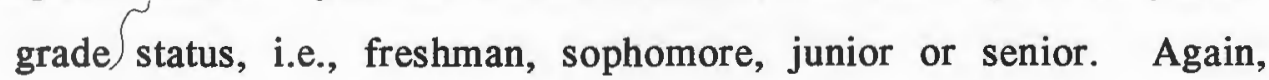
you are to answer all items that apply to you.

Following this, the group of subjects were asked if they had any questions about how to complete the questionnaire. The instructions were repeated and clarified for those who failed to indicate a clear understanding. Analysis

The Self-Disclosure Questionnaire was scored by summarizing the responses to the 60 items for each target person. A rating of 1 on an item means that the person will lie or misrepresent oneself to the target person. A rating of 2 on an item means that the subject will disclose nothing about this aspect of himself or herself. A rating of 3 means that the subject will talk very little about this area. A rating of 4 means that the subject will talk in general terms about this aspect of himself/herself. A rating of 5 means that the subject will disclose quite a bit about this area, and a rating 
of 6 means that the subject will disclose fully on this topic to the target person.

Each of the 6 categories of information has 10 items and the range of scores for each category is 1 to 6 . Since the questionnaire included 60 items and there are 4 target persons, a total of 240 entries were made by each subject. The means of the subscale scores and the means of the total scores were used in several analyses. A mean score of 3 indicates low selfdisclosure while a mean score of 5 indicates high self-disclosure. The possible range of scores that a subject can obtain under Jourard's SelfDisclosure Questionnaire ranges from a total of 60 to 360 . Although total scores were computed for individuals and cell groups as a step in the ANOVA procedure, only the means of these groups are used in the various analyses. Thus, the means and standard deviations are reported in Tables 2 through 6 for the ANOVA and in Tables 8 through 12 for the Multivariate Analysis of Variance. 


\section{CHAPTER III}

\section{RESULTS}

\section{Results for Total Self-Disclosure}

In order to examine the effects of race and gender on overall selfdisclosure, a six-factor mixed-model Analysis of Variance (ANOVA) was performed on the subject's total self-disclosure. The four between-subject factors were: subject's school (predominantly Black university predominantly White university), subject's gender (male-female), examiner's race (Black-White), and examiner's gender (male-female). The two withinsubject factors were: target race (Black-White) and target gender (malefemale). These six factors generated an ANOVA table with 63 F-tests for the 63 main effects and interactions. Because of the high probability of making a Type I error (that is, obtaining spurious statistical significance), a Bonferrani-type adjustment (Keppell, 1982) was made in assessing the statistical significance of an effect in the ANOVA table. To keep the level of significance at .05 for the whole ANOVA table, an individual effect or an Ftest was considered statistically significant if it reached the .001 level. This level of significance was chosen because $.05 / 63$ (where 63 is the number of F-tests in an ANOVA table) is approximately equal to .001.

Table 1 summarizes the ANOVA results for total self-disclosure. The complexity of the table, with its 63 F-tests, requires a short explanation. The first four columns contain traditional ANOVA information: Sources (of variation), Mean Squares, Degrees of Freedom (df) and F-tests. The fifth column, entitled "Table of Relevant Means", is included as an aid to the reader because associated with each of the 63 F-tests is a table of means, many of which are very complex (e.g., those associated with the 4, 5 and 6 factor interaction). Since most of the F-tests were not statistically significant, it was not necessary to present such a voluminous set of 63 tables of means. Instead, tables of means are only presented when the F- 
test associated with them is statistically significant. Thus, a number in the "Table of Relevant Means" column indicates which table the reader should refer to. Furthermore, a table number is only indicated when its associated F-test is statistically significant.

From Table 1 it can be seen that for total self-disclosure, a significant difference for target gender was obtained $(\mathrm{F}=38.72$, $\mathrm{df}=1,224, \mathrm{p}<.0001)$. The means in Table 2 reveal that subjects reported disclosing more when the target person was female (Mean $=3.93$ ) than when the target person was male (Mean $=3.87$ ). For target race, whose means are shown in Table 3, a significant finding was also found $(F=247.10, \mathrm{df}=1,224, \mathrm{p}<.0001)$ with subjects reporting higher rates when disclosing to a Black target person (Mean $=4.19$ ) than to a White target person (Mean $=3.65$ ). No significant effects were obtained for subject's school $(\mathrm{F}=1.63$, df $=1,224$, n.s.), examiner race $(F=0.47, d f=1,224$, n.s. $)$, subject gender $(F=0.03$, $\mathrm{df}=$ $1,224$, n.s. $)$ or examiner gender $(\mathrm{F}=2.00$, $\mathrm{df}=1,224$, n.s. $)$.

In terms of the six predictions presented at the end of Chapter 1, these analyses show that predictions 3 and 6 were confirmed by the data. That is, subjects disclosed more when the target person was Black than when the target person was White (prediction 3), and they disclosed more to female target persons than to males (prediction 6). The predictions concerned with racial composition on campus, race of examiner, gender of examiner, and subject gender were not confirmed.

Table 1 also shows one significant 2-way interaction (Target Gender $\mathrm{x}$ Subject Gender) and two significant 3-way interactions (Target Race $\mathrm{x}$ Examiner Race $\mathrm{x}$ Examiner Gender, and Target Gender $\mathrm{x}$ Target Race $\mathrm{x}$ Subject Gender). For the 2-way interaction, Target Gender $x$ Subject Gender, the $F$ statistic was $25.20(\mathrm{df}=1,224, \mathrm{p}<.0001)$. For the two significant 3-way interactions, the results were: Target Race $\mathrm{x}$ Examiner Race $\mathrm{x}$ Examiner Race $\mathrm{x}$ Examiner Gender $(\mathrm{F}=12.91$, $\mathrm{df}=1,224, \mathrm{p}<.001)$, Target Gender $\mathrm{x}$ Target Race $x$ Subject Gender $(F=16.02$, df $=1,224, p<.001)$. Follow-up tests on 
cell means were then performed using Tukey's H.S.D. post hoc procedure, as recommended by Winer (1971). The results of these tests are presented in the next three paragraphs.

For the 2-way interaction between Target Gender and Subject Gender (Table 4) the Tukey procedure showed that female subjects disclosed significantly more when the target person was female (Mean $=4.02$ ) than when the target person was male (Mean $=3.83$ ). However, males did not report any significant target gender differences.

The means related to the 3-way interaction, Target Race $\mathrm{x}$ Examiner Race x Examiner Gender, were tested by examining Target Race differences within each combination of Examiner Race and Examiner Gender (Table 5). The Tukey post hoc tests showed that for all four combinations of Examiner Race and Examiner Gender (Black-Males, Black-Females, White-Males and White-Females) more disclosure was made to Black target persons than to White target persons. This lack of differential findings under all combinations of Examiner Race and Examiner Gender is not surprising when the F-value for the main effect of target race $(247.10$, from Table 1) is compared with the F-value for this 3-way interaction (12.91, from Table 1). In summary, although the interaction was statistically significant, it was nevertheless negligible when compared with the huge main effect for target race: subjects reported more disclosure to Blacks than to Whites under all combinations of examiner race and examiner gender.

The means and post-hoc tests for the 3-way interaction of Target Gender x Target Race x Subject Gender (Table 6) show a similar pattern to the previously discussed 3-way interaction. For all combinations of Subject Gender and Target Gender, subjects reported more disclosure when the target person was Black than when the target person was White.

\section{Results for Self-Disclosure Sub-Scales}

In order to assess the effects of subject school, subject gender, examiner's gender, examiner's race, target gender, and target race on the 
subscales of self-disclosure, a six-factor Multivariate Analysis of Variance (MANOVA) was performed on the six self-disclosure subscales: Attitudes, Tastes, Work, Money, Personality, and Body. When the Multivariate F was statistically significant, follow-up univariate analyses were performed on the separate subscales. The level of significance used for individual effects was $\mathrm{p}<.001$, as explained in the previous section. Table 7 presents a summary of these analyses. (The full ANOVA tables for each subscale are given in Appendix D through I.)

The results obtained for the self-disclosure subscales were, in general, similar to those found for total self-disclosure: target race and target gender emerged as significant effects. From the F-values in Table 7 and means in Table 8, it can be seen that target race produced particularly large effects for all self-disclosure subscales, with subjects reporting more disclosure to Blacks than to Whites.

The effects for Target Gender were statistically significant for the following subscales: Attitudes $(F=24.81$, $d f=1,224, p<.0001)$, Tastes $(F=$ 23.13, df $=1,224, \mathrm{p}<.001)$, Personality $(\mathrm{F}=25.59$, df $=1,224, \mathrm{p}<.001)$, and Body $(\mathrm{F}=63.38, \mathrm{p}<.0001)$. For these areas of self-disclosure, subjects reported more disclosures to females than to males (Table 9).

The means and post hoc tests for Target Gender are presented in Table 10. The pattern of means in this table shows a higher degree of selfdisclosure by female subjects than by male subjects.

Tables 11 and 12 present means and post hoc tests for the 2-way interactions involving Target Race. The pattern of means confirms the main effect for this factor: subjects reported more self-disclosure to Blacks than to Whites. 
TABLE 1. ANOVA SUMMARY OF TOTAL SELF-DISCLOSURE BY SUBJECT COLLEGE, SUB,JECT GENDER, EXAMINER GENDER,EXAMINER RACE,TARGET GENDER, AND TARGET RACE

\begin{tabular}{ccccc} 
Source & $\begin{array}{l}\text { Mean } \\
\text { Square }\end{array}$ & df & $F$ & $\begin{array}{l}\text { Table of } \\
\text { Relevant } \\
\text { Means }\end{array}$ \\
\hline
\end{tabular}

Between Subjects Effects

SSchool

SGender

SSchool x SGender

ExRace

SSchool $x$ ExRace

SGender $x$ ExRace

SSchool x SGender $x$ ExRace

ExGender

SSchool x ExGender

SGender $x$ ExGender

SSchool $x$ SGender $x$ ExGender

ExRace $x$ ExGender

SSchool $x$ ExRace $x$ ExGender

SGender $x$ ExRace $x$ ExGender

SSchool x SGender x ExRace x ExGender

ERROR
2.01

0.04

1.30

0.58

0.84

0.49

0.69

2.48

1.43

0.25

3.48

0.84

1.75

6.02

1.51

123.78
1.63

0.03

1.05

0.47

0.68

0.40

0.55

2.00

1.16

0.21

2.81

0.68

1.42

4.86

4.86
1.22 
Table 1 (continued)

\begin{tabular}{|c|c|c|c|c|}
\hline Source & $\begin{array}{r}\text { Mean } \\
\text { Square }\end{array}$ & df & $\mathbf{F}$ & $\begin{array}{l}\text { Table of } \\
\text { Relevant } \\
\text { Means }\end{array}$ \\
\hline
\end{tabular}

Within Subjects Effects

Involving Target Gender

TGender

TGender $x$ SSchool

2.54

0.03

1.66

TGender $x$ SGender

0.04

TGender $x$ SSchool $x$ SGender

TGender $x$ ExRace

0.01

TGender $x$ SSchool $x$ ExRace

0.02

TGender $x$ SGender $x$ ExRace

0.36

TGender $x$ SSchool $x$ SGender $x$ ExRace

0.07

TGender $x$ ExGender

0.00

TGender x SSchool $x$ ExGender

0.01

TGender $x$ SGender $x$ ExGender

0.08

TGender $x$ SSchool $x$ SGender $x$ ExGender

0.13

TGender $x$ ExRace $x$ ExGender

0.00

TGender $x$ SSchool $x$ ExRace $x$ ExGender

0.04

TGender $x$ SGender $x$ ExRace $x$ ExGender

0.01

$38.72 * *$

0.48

$25.20 * *$

0.64

0.10

0.25

5.43

1.06

0.00

0.11

1.26

2.02

0.07

0.56

TGender $x$ SSchool $x$ SGender $x$ ExRace $x$ ExGender

ERROR (TGender)

0.00

0.08

0.06

1

0.00 
Table 1 (continued)

Source $\begin{gathered}\text { Mean } \\
\text { Square }\end{gathered}$ df $F \quad$\begin{tabular}{c}
$\begin{array}{c}\text { Table of } \\
\text { Relevant } \\
\text { Means }\end{array}$ \\
\hline
\end{tabular}

Within Subject Effects

Involving Target Race

TRace

TRace x SSchool

TRace $x$ SGender

TRace x SSchool x SGender

TRace $x$ ExRace

TRace $x$ SSchool $x$ ExRace

TRace $x$ SGender $x$ ExRace

TRace $x$ SSchool x SGender $x$ ExRace

TRace $x$ ExGender

TRace x SSchool x ExGender

TRace $x$ SGender $x$ ExGender

TRace x SSchool x SGender x ExGender

TRace $x$ ExRace $x$ ExGender

TRace $x$ SSchool $x$ ExRace $x$ ExGender

TRace x SGender $x$ ExRace $x$ ExGender

TRace $x$ SSchool $x$ SGender $x$ ERace

$$
x \text { ExGender }
$$

ERROR (TRace)

$\begin{array}{cccc}67.84 & 1 & 247.10 * * & 3 \\ 0.00 & 1 & 0.01 & \\ 0.01 & 1 & 0.02 & \\ 0.11 & 1 & 0.42 \\ 2.52 & 1 & 9.16 \\ 0.05 & 1 & 0.17 \\ 2.30 & 1 & 8.38 \\ 0.10 & 1 & 0.38 \\ 0.40 & 1 & 1.45 & \\ 0.14 & 1 & 0.50 \\ 0.15 & 1 & 0.55 & \\ 0.71 & 1 & 2.60 & \\ 3.54 & 1 & 12.91 * & 5 \\ 0.64 & 1 & 2.33 \\ 0.00 & 1 & 0.00 \\ 0.73 & 1 & 2.66 & \\ 0.274 & 224 & --\end{array}$


Table 1 (continued)

\begin{tabular}{|c|c|c|c|c|}
\hline Source & $\begin{array}{r}\text { Mean } \\
\text { Square }\end{array}$ & df & $\begin{array}{l}\mathrm{T} \\
\mathrm{R} \\
\mathrm{P}\end{array}$ & $\begin{array}{l}\text { Table of } \\
\text { Relevant } \\
\text { Means }\end{array}$ \\
\hline TGender $x$ TRace & 0.04 & 1 & 2.77 & \\
\hline TGender $\mathrm{x}$ TRace $\mathrm{x}$ SSchool & 0.07 & 1 & 4.24 & \\
\hline TGender $x$ TRace $x$ SGender & 0.26 & 1 & $16.02 * *$ & 6 \\
\hline TGender $\times$ TRace $\times$ SSchool $x$ SGender & 0.03 & 1 & 1.87 & \\
\hline TGender $x$ TRace $x$ ExRace & 0.09 & 1 & 5.37 & \\
\hline TGender x TRace x SSchool x ExRace & 0.02 & 1 & 1.40 & \\
\hline TGender $x$ TRace $x$ SGender $x$ ExRace & 0.00 & 1 & 0.18 & \\
\hline $\begin{array}{l}\text { TGender } \times \text { TRace } \times \text { SSchool x SGender } \\
\text { xExRace }\end{array}$ & 001 & 1 & 0.55 & \\
\hline TGender $\mathrm{x}$ TRace $\mathrm{x}$ ExGender & 0.00 & 1 & 0.17 & \\
\hline TGender x TRace x SSchool x ExGender & 0.02 & 1 & 1.32 & \\
\hline $\begin{array}{l}\text { TGender x TRace x SGender x ExGender } \\
\text { TGender } x \text { TRace } x \text { SSchool x SGender }\end{array}$ & 0.05 & 1 & 3.36 & \\
\hline x ExGender & 0.01 & 1 & 0.41 & \\
\hline $\begin{array}{l}\text { TGender } \times \text { TRace } \times \text { ExRace } \times \text { ExGender } \\
\text { TGender } \times \text { TRace } \times \text { SSchool } \times \text { ExRace }\end{array}$ & 0.00 & 1 & 0.02 & \\
\hline $\begin{array}{l}\text { x ExGender } \\
\text { TGender } x \text { TRace } x \text { SGender } x \text { ExRace }\end{array}$ & 0.01 & 1 & 0.84 & \\
\hline $\begin{array}{l}\text { x ExGender } \\
\text { TGender } x \text { TRace } x \text { SSchool x SGender }\end{array}$ & 0.09 & 1 & 5.78 & \\
\hline $\mathrm{x}$ ExRace $\mathrm{x}$ ExGender & 0.01 & 1 & 0.68 & \\
\hline ERROR (TGender x TRace) & 0.02 & 224 & -- & \\
\hline 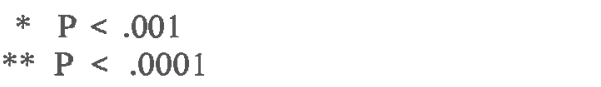 & & & & \\
\hline
\end{tabular}


TABLE 2. MEANS AND STANDARD DEVIATION ON TOTAL SELF-DISCLOSURE BY TARGET GENDER

\section{TARGET GENDER}

\begin{tabular}{cccc} 
& & & \\
2 & & & \\
240 & Mean & 3.87 & 3.93 \\
& S.D. & 0.58 & 0.57 \\
\hline
\end{tabular}

TABLE 3. MEANS AND STANDARD DEVIATION ON TOTAL SELF-DISCLOSURE BY TARGET RACE

TARGET RACE

$\begin{array}{cccc}\mathrm{n} & \text { Black } & \text { White } \\ 240 & \text { Mean } & 4.19 & 3.65 \\ & \text { S.D. } & 0.57 & 0.68\end{array}$


Table 4. Means and Standard Deviation on Total SelfDisclosure By Subject Gender and Target Gender

TARGET GENDER

\begin{tabular}{|c|c|c|c|c|c|}
\hline $\begin{array}{l}\text { Subject } \\
\text { Gender }\end{array}$ & $\mathbf{n}$ & & Male & Female & $\begin{array}{l}\text { Tukey H.S.D. } \\
\text { Post Hoc Test }\end{array}$ \\
\hline Male & 120 & $\begin{array}{l}\text { Mean } \\
\text { S.D. }\end{array}$ & $\begin{array}{l}3.91 \\
0.58\end{array}$ & $\begin{array}{l}3.93 \\
0.59\end{array}$ & n.s. \\
\hline Female & 120 & $\begin{array}{c}\text { Mean } \\
\text { S.D. }\end{array}$ & $\begin{array}{l}3.83 \\
0.59\end{array}$ & $\begin{array}{l}4.02 \\
0.56\end{array}$ & $\mathrm{p}<.01$ \\
\hline
\end{tabular}

TABLE 5. MEANS AND STANDARD DEVIATION OF TOTAL SELFDISCLOSURE BY TARGET RACE, EXAMINER RACE AND EXAMINER GENDER

\begin{tabular}{|c|c|c|c|c|c|c|}
\hline \multirow{2}{*}{$\begin{array}{l}\text { Examiner } \\
\text { Race }\end{array}$} & \multirow{2}{*}{$\begin{array}{l}\text { Examiner } \\
\text { Gender }\end{array}$} & \multirow[b]{2}{*}{ n } & & \multicolumn{2}{|c|}{ Target Race } & \multirow{2}{*}{$\begin{array}{l}\text { Tukey H.S.D. } \\
\text { Post Hoc Test }\end{array}$} \\
\hline & & & & Black & White & \\
\hline \multirow{4}{*}{ Black } & \multirow[t]{2}{*}{ Males } & \multirow[t]{2}{*}{60} & Mean & 4.22 & 3.74 & \multirow[t]{2}{*}{$\mathrm{p}<.01$} \\
\hline & & & S.D. & 0.59 & 0.73 & \\
\hline & \multirow[t]{2}{*}{ Females } & \multirow[t]{2}{*}{60} & Mean & 4.22 & 3.41 & \multirow[t]{2}{*}{$\mathrm{p}<.01$} \\
\hline & & & S.D. & 0.50 & 0.68 & \\
\hline \multirow{4}{*}{ White } & Males & 60 & Mean & 4.22 & 3.71 & \multirow{2}{*}{$\mathrm{p}<.01$} \\
\hline & & & S.D. & 0.58 & 0.62 & \\
\hline & \multirow[t]{2}{*}{ Females } & \multirow[t]{2}{*}{60} & Mean & 4.09 & 3.75 & \multirow[t]{2}{*}{$p<.01$} \\
\hline & & & S.D. & 0.61 & 0.63 & \\
\hline
\end{tabular}


TABLE 6. MEANS AND STANDARD DEVIATION ON TOTAL SELFDISCLOSURE BY TARGET GENDER, TARGET RACE AND SUBJECT GENDER

\begin{tabular}{|c|c|c|c|c|c|c|}
\hline \multirow{2}{*}{$\begin{array}{l}\text { Subject } \\
\text { Gender }\end{array}$} & \multirow{2}{*}{$\begin{array}{l}\text { Target } \\
\text { Gender }\end{array}$} & \multirow[b]{2}{*}{$\mathbf{n}$} & \multicolumn{3}{|c|}{ Target Race } & \multirow{2}{*}{$\begin{array}{l}\text { Tukey H.S.D. } \\
\text { Post Hoc Test }\end{array}$} \\
\hline & & & & Black & White & \\
\hline \multirow{3}{*}{ Male } & Males & 120 & Mean & 4.18 & 3.63 & $\mathrm{p}<.01$ \\
\hline & & & & & & \\
\hline & Females & 120 & $\begin{array}{l}\text { Mean } \\
\text { S.D. }\end{array}$ & $\begin{array}{l}4.18 \\
0.68\end{array}$ & 3.67 & $p<.01$ \\
\hline \multirow{2}{*}{ Female } & Males & 120 & $\begin{array}{l}\text { Mean } \\
\text { S.D. }\end{array}$ & $\begin{array}{l}4.18 \\
0.69\end{array}$ & 3.59 & $p<.01$ \\
\hline & Females & 120 & $\begin{array}{l}\text { Mean } \\
\text { S.D. }\end{array}$ & $\begin{array}{l}4.31 \\
0.70\end{array}$ & 3.73 & $\mathrm{p}<.01$ \\
\hline
\end{tabular}




\section{Results for Self-Disclosure Sub-Scales}

In order to assess the effects of subject school, subject gender, examiner's gender, examiner's race, target gender, and target race on the subscales of self-disclosure, a six-factor Multivariate Analysis of Variance (MANOVA) was performed on the six self-disclosure subscales. (These 6 subscales were titled Attitudes, Tastes, Work, Money, Personality, and Body.) If the multivariate $F$ is statistically significant, then follow-up univariate analyses will be performed on the separate subscales. The level of significance used for individual effects was $P<.001$, as explained in the previous section. Table 7 presents a summary of these analyses. (The full ANOVA tables for each subscale are given in Appendix D through I.)

The results obtained for the subscales were, with some exceptions, similar to those found for total self-disclosure: target race and target gender emerged as significant effects. Subjects disclosed more when the target person was female than when the target person was male in areas of Attitudes $(\mathrm{F}=24.81 \mathrm{p}<.0001)$, Tastes $(\mathrm{F}=23.13 \mathrm{p}<.001)$, Personality $(\mathrm{F}=$ $25.59 \mathrm{p}<.001)$, and Body $(\mathrm{F}=63.38 \mathrm{p}<.0001)$.

There were also very large effects for target race as can be seen from the $F$ values in Table 7 and the means in Table 10. If the race of the target person was Black, subjects disclosed more in all subject areas than if the race of the target person was White.

Several significant interaction effects were found on the subscales. A significant difference in the reported rates of self-disclosure was found for the target Gender $x$ Subject Gender interaction. A Tukey follow-up test found differences between subjects when disclosing to male and female targets in the areas of Attitudes $(F=63.44 p<.001)$, Work $(F=13.69 p<$ $.01)$, Money $(F=38.93 p<.001)$ and Body $(F=20.77 p<.001)$. The differences between males and females in disclosure rates on various topics do not follow a clear cut consistent pattern (the Means and Standard Deviation are presented in Table 10). 
TABLE 7. SUMMARY OF MULTIVARIATE AND UNIVARIATE ANOVAS ON SELF DISCLOSURE SUBSCALES BY SUBJECT COLLEGE, SUBJECT GENDER, EXAMINER GENDER, EXAMINER RACE, TARGET GENDER, AND TARGET RACE

$\begin{array}{cclll} & \text { Multi- } & \text { Self-Disclosure } & \text { Uni- } & \text { Table of } \\ \text { Source } & \text { Variate } & \text { Subscales } & \text { Variate } & \text { Relevant } \\ & \text { F } & & \text { F } & \text { Means }\end{array}$

Between Subjects Effects

\begin{tabular}{ll} 
SSchool & 0.98 \\
SGender & 1.21 \\
SSchool x SGender & 2.17 \\
ExRace & 0.36 \\
SSchool x ExRace & 1.88 \\
SGender x ExRace & 1.28 \\
SSchool x SGender x ExRace & 1.07 \\
ExGender & 1.09 \\
SSchool x ExGender & 1.14 \\
SGender x ExGender & 1.51 \\
SSchool x SGender x ExGender & 1.57 \\
ExRace x ExGender & 0.76 \\
SSchool x ExRace x ExGender & 0.90 \\
SGender x ExRace x ExGender & 1.43 \\
SSchool x SGender x ExRace & \\
\multicolumn{1}{c}{ x ExGender } & 2.08
\end{tabular}

Within Subject Effects

Involving Target_Gender

$\begin{array}{lcc}\text { Attitudes } & 24.81 * * & 9 \\ \text { Tastes } & 23.18 * & 9 \\ \text { Work } & 6.11 & \\ \text { Money } & 0.44 & \\ \text { Personality } & 25.59 * * & 9 \\ \text { Body } & 63.38 * * & 9\end{array}$




\begin{tabular}{|c|c|c|c|c|}
\hline TGender x SSchool & 0.30 & & & \\
\hline \multirow[t]{6}{*}{ TGender $\times S$ Gender } & $19.04 * *$ & Attitudes & $63.44 *$ & 10 \\
\hline & & Tastes & 0.22 & \\
\hline & & Work & $13.69 *$ & 10 \\
\hline & & Money & $38.93 * *$ & 10 \\
\hline & & Personality & 2.45 & \\
\hline & & Body & $20.77 * *$ & 10 \\
\hline TGender x SSchool x SGender & 0.54 & & & \\
\hline TGender $x$ ExRace & 2.79 & & & \\
\hline TGender x SSchool x ExRace & 1.50 & & & \\
\hline TGender x SGender $x$ ExRace & 1.81 & & & \\
\hline \multicolumn{5}{|l|}{ TGender $\times$ SSchool $\times$ SGender } \\
\hline$x$ ExRace & 1.85 & & & \\
\hline TGender x ExGender & 2.46 & & & \\
\hline TGender x SSchool $x$ ExGender & 1.65 & & & \\
\hline TGender x SGender x ExGender & 0.83 & & & \\
\hline \multicolumn{5}{|l|}{ TGender $\times$ SSchool $\times$ SGender } \\
\hline x ExGender & 1.57 & & & \\
\hline TGender $x$ ExRace $x$ ExGender & 1.17 & & & \\
\hline \multicolumn{5}{|l|}{ TGender x SSchool x ExRace } \\
\hline x ExGender & 1.26 & & & \\
\hline \multicolumn{5}{|l|}{ TGender $x$ SGender $x$ ExRace } \\
\hline x ExGender & 0.39 & & & \\
\hline \multicolumn{5}{|l|}{ TGender $\times$ SSchool $\times$ SGender } \\
\hline $\mathrm{x}$ ExRace $\times$ ExGender & 1.29 & & & \\
\hline \multicolumn{5}{|l|}{ Within Subject Effects } \\
\hline \multicolumn{5}{|l|}{ Involving Target Race } \\
\hline \multirow[t]{6}{*}{ TRace } & $50.58 * *$ & Attitudes & $248.04 * *$ & 8 \\
\hline & & Tastes & $198.85 * *$ & 8 \\
\hline & & Work & $184.77 * *$ & 8 \\
\hline & & Money & $100.90 * *$ & 8 \\
\hline & & Personality & $196.45 * *$ & 8 \\
\hline & & Body & $130.74 * *$ & 8 \\
\hline TRace x SSchool & 1.54 & & & \\
\hline TRace $\times$ SGender & 0.80 & & & \\
\hline TRace $\times$ S School x SGender & 0.37 & & & \\
\hline \multirow[t]{6}{*}{ TRace $x$ ExRace } & $5.14 *$ & Attitu des & $19.70 * *$ & 11 \\
\hline & & Tastes & $16.09 * *$ & 11 \\
\hline & & Work & 0.53 & \\
\hline & & Money & 0.08 & \\
\hline & & Personality & 1.40 & \\
\hline & & Body & 0.51 & \\
\hline TRace $\times$ SSchool $\times$ ExRace & 0.75 & & & \\
\hline TRace x SGender $\times$ ExRace & 2.71 & & & \\
\hline \multicolumn{5}{|l|}{ TRace $\times$ SSchool $\times$ SGender } \\
\hline $\mathrm{x}$ ExRace & 1.49 & & & \\
\hline TRace $x$ ExGender & 1.73 & & & \\
\hline TRace x SSchool x ExGender & 0.60 & & & \\
\hline TRace $x$ SGender $x$ ExGender & 2.39 & & & \\
\hline \multicolumn{5}{|l|}{ TRace $\times$ SSchool $\times$ SGender } \\
\hline x ExGender & 0.82 & & & \\
\hline \multicolumn{5}{|l|}{ TRace x SSchool x ExRace } \\
\hline $\mathrm{x}$ ExGender & 2.64 & & & \\
\hline \multicolumn{5}{|l|}{ TRace $\times$ SGender $x$ ExRace } \\
\hline x ExGender & 1.35 & & & \\
\hline TRace $\times$ SGender x ExRace & & & & \\
\hline x ExGender & 1.08 & & & \\
\hline
\end{tabular}


$x$ ExRace $x$ ExGender

1.19

Within Subject Effects

Involving Target Gender $x$ Target Race

TGender

3.04

TGender $x$ TRace $x$ SSchool

1.23

TGender $x$ TRace $x$ SGender

$6.17 *$

$\begin{array}{lc}\text { Attitudes } & 11.80 * \\ \text { Tastes } & 4.59 \\ \text { Work } & 4.37 \\ \text { Money } & 24.21 * * \\ \text { Personality } & 1.16 \\ \text { Body } & 1.93\end{array}$

12

TGender $\mathrm{x}$ TRace $\mathrm{x}$ SSchool $x$ SGender

TGender $x$ TRace $x$ ExRace

TGender $x$ TRace $x$ SSchool $x$ ExRace

TGender $x$ TRace $x$ SGender $x$ ExRace

TGender $x$ TRace $x$ SSchool $x$ SGender $x$ ExRace

TGender $x$ TRace $x$ SSchool $x$ ExGender

TGender $x$ TRace $x$ SSchool $x$ ExGender

TGender $x$ TRace $x$ SGender $x$ ExGender

TGender $x$ TRace $x$ SSchool $x$ SGender $x$ ExGender $\quad 0.47$

TGender $x$ TRace $x$ ExRace

$$
x \text { ExGender } 1.18
$$

TGender $x$ TRace $x$ SSchool $x$ ExRace $x$ ExGender $\quad 1.72$

TGender $x$ TRace $x$ SGender $x$ ExRace $x$ ExGender

TGender $x$ TRace $x$ SSchool $x$ SGender $x$ ExRace $x$ ExGender

$* * \mathrm{p}<.0001$ 
TABLE 8. MEANS AND STANDARD DEVIATION ON SELFDISCLOSURE SUBSCALES BY TARGET RACE

\begin{tabular}{|c|c|c|c|c|}
\hline \multirow[b]{2}{*}{ Subscale } & \multirow[b]{2}{*}{$\mathrm{n}$} & & \multicolumn{2}{|c|}{ Target Race } \\
\hline & & & Black & White \\
\hline Attitudes & 240 & $\begin{array}{l}\text { Mean } \\
\text { S.D. }\end{array}$ & $\begin{array}{l}4.76 \\
0.65\end{array}$ & $\begin{array}{l}4.17 \\
0.80\end{array}$ \\
\hline Tastes & 240 & $\begin{array}{l}\text { Mean } \\
\text { S.D. }\end{array}$ & $\begin{array}{l}5.16 \\
0.74\end{array}$ & $\begin{array}{l}4.68 \\
0.97\end{array}$ \\
\hline Work & 240 & $\begin{array}{l}\text { Mean } \\
\text { S.D. }\end{array}$ & $\begin{array}{l}4.63 \\
0.82\end{array}$ & $\begin{array}{l}3.98 \\
1.00\end{array}$ \\
\hline Money & 240 & $\begin{array}{l}\text { Mean } \\
\text { S.D. }\end{array}$ & $\begin{array}{l}3.05 \\
0.87\end{array}$ & $\begin{array}{l}2.67 \\
0.84\end{array}$ \\
\hline Personality & 240 & $\begin{array}{l}\text { Mean } \\
\text { S.D. }\end{array}$ & $\begin{array}{l}3.73 \\
0.79\end{array}$ & $\begin{array}{l}3.12 \\
0.83\end{array}$ \\
\hline Body & 240 & $\begin{array}{l}\text { Mean } \\
\text { S.D. }\end{array}$ & $\begin{array}{l}3.78 \\
0.88\end{array}$ & $\begin{array}{l}3.28 \\
0.93\end{array}$ \\
\hline
\end{tabular}


TABLE 9. MEANS AND STANDARD DEVIATION ON SELFDISCLOSURE SUBSCALES BY TARGET GENDER

\begin{tabular}{|c|c|c|c|c|}
\hline \multirow[b]{2}{*}{ Subscale } & \multirow[b]{2}{*}{$\mathrm{n}$} & & \multicolumn{2}{|c|}{ Target Gender } \\
\hline & & & Male & Female \\
\hline \multirow[t]{2}{*}{ Attitudes } & 240 & Mean & 4.44 & 4.52 \\
\hline & & S.D. & 0.66 & 0.67 \\
\hline \multirow[t]{2}{*}{ Tastes } & 240 & Mean & 4.87 & 4.97 \\
\hline & & S.D. & 0.82 & 0.78 \\
\hline \multirow[t]{2}{*}{ Personality } & 240 & Mean & 3.35 & 3.50 \\
\hline & & S.D. & 0.77 & 0.76 \\
\hline \multirow[t]{2}{*}{ Body } & 240 & Mean & 3.40 & 3.65 \\
\hline & & S.D. & 0.87 & 0.88 \\
\hline
\end{tabular}

TABLE 10. MEANS AND STANDARD DEVIATION ON SELFDISCLOSURE SUBSCALES BY TARGET GENDER AND SUBJECT GENDER

\begin{tabular}{|c|c|c|c|c|c|c|}
\hline \multirow[b]{2}{*}{ Subscale } & \multicolumn{3}{|c|}{ Subject } & \multicolumn{2}{|c|}{ Target Gender } & \multirow{2}{*}{$\begin{array}{l}\text { Tukey H.S.D. } \\
\text { Post Hoc Test }\end{array}$} \\
\hline & n & Gender & & Male & Female & \\
\hline \multirow[t]{4}{*}{ Attitudes } & 120 & male & Mean & 4.44 & 4.48 & n.s. \\
\hline & & & S.D. & 0.66 & 2.68 & \\
\hline & & female & Mean & 4.44 & 4.64 & $\mathrm{p}<.01$ \\
\hline & & & S.D. & 0.63 & 0.65 & \\
\hline \multirow[t]{4}{*}{ Work } & 120 & male & Mean & 4.28 & 4.25 & n.s. \\
\hline & & & S.D. & 0.86 & 0.88 & \\
\hline & & female & Mean & 4.29 & 4.42 & $\mathrm{p}<.01$ \\
\hline & & & S.D. & 0.84 & 0.81 & \\
\hline \multirow[t]{4}{*}{ Money } & 120 & male & Mean & 3.00 & 2.89 & $\mathrm{p}<.01$ \\
\hline & & & S.D. & 0.84 & 0.82 & \\
\hline & & female & Mean & 2.73 & 2.83 & $\mathrm{p}<.01$ \\
\hline & & & S.D. & 0.79 & 0.79 & \\
\hline \multirow[t]{4}{*}{ Body } & 120 & male & Mean & 3.52 & 3.63 & n.s. \\
\hline & & & S.D. & 0.87 & 0.92 & \\
\hline & & female & Mean & 3.28 & 3.68 & $\mathrm{p}<.01$ \\
\hline & & & S.D. & 0.85 & 0.45 & \\
\hline
\end{tabular}


TABLE 11. MEANS AND STANDARD DEVIATION ON SELFDISCLOSURE SUBSCALES BY TARGET RACE AND EXAMINER RACE

\begin{tabular}{|c|c|c|c|c|c|c|}
\hline \multirow[b]{2}{*}{ Subscale } & \multirow[b]{2}{*}{$\mathbf{n}$} & \multirow{2}{*}{$\begin{array}{l}\text { Examiner } \\
\text { Race }\end{array}$} & & \multicolumn{2}{|c|}{ Target Race } & \multirow{2}{*}{$\begin{array}{l}\text { Tukey H.S.D. } \\
\text { Post Hoc Test }\end{array}$} \\
\hline & & & & Black & White & \\
\hline \multirow[t]{4}{*}{ Attitudes } & 120 & Black & Mean & 4.89 & 4.11 & $\mathrm{p}<.01$ \\
\hline & & & S.D. & 0.57 & 0.82 & \\
\hline & & White & Mean & 4.67 & 4.24 & $p<.01$ \\
\hline & & & S.D. & 0.73 & 0.79 & \\
\hline \multirow[t]{4}{*}{ Tastes } & 120 & Black & Mean & 5.23 & 4.58 & $\mathrm{p}<.01$ \\
\hline & & & S.D. & 0.73 & 1.00 & \\
\hline & & White & Mean & 5.09 & 4.80 & $\mathrm{p}<.01$ \\
\hline & & & S.D. & 0.85 & 0.89 & \\
\hline
\end{tabular}

TABLE 12. MEANS AND STANDARD DEVIATIONS ON SELFDISCLOSURE SUBSCALES BY TARGET RACE AND TARGET GENDER

\begin{tabular}{|c|c|c|c|c|c|c|}
\hline \multirow[b]{2}{*}{ Subscale } & \multirow[b]{2}{*}{ n } & \multirow{2}{*}{$\begin{array}{l}\text { Target } \\
\text { Gender }\end{array}$} & \multicolumn{3}{|c|}{ Target Race } & \multirow{2}{*}{$\begin{array}{l}\text { Tukey H.S.D. } \\
\text { Post Hoc Test }\end{array}$} \\
\hline & & & & Black & White & \\
\hline \multirow[t]{4}{*}{ Attitudes } & 120 & Male & Mean & 4.75 & 4.13 & $\mathrm{p}<.01$ \\
\hline & & & S.D. & 0.66 & 0.80 & \\
\hline & & Female & Mean & 4.81 & 4.22 & $\mathrm{p}<.01$ \\
\hline & & & S.D. & 0.67 & 0.83 & \\
\hline \multirow[t]{4}{*}{ Money } & 120 & Male & Mean & 3.05 & 2.68 & $\mathrm{p}<.01$ \\
\hline & & & S.D. & 0.86 & 0.81 & \\
\hline & & Female & Mean & 3.04 & 2.67 & $\mathrm{p}<.01$ \\
\hline & & & S.D. & 0.86 & 0.81 & \\
\hline
\end{tabular}




\section{CHAPTER IV}

\section{DISCUSSION}

The chief aim of the present study was to determine the preferences of Black college students from two different colleges for Black and White counselors from the extent to which they were willing to self-disclose to each of four target persons: Black male, White male, Black female, and White female, as measured by Jourard's Self-Disclosure Questionnaire (revised). The students were also interviewed by examiners who varied by race and gender in this investigation. The subjects were Black, Americanborn students who were enrolled in two major universities in the Washington, D.C. area during the 1986-1987 academic year.

The results of the investigation were analyzed in six major categories: sex differences, school differences, examiner race differences, examiner gender differences, target race differences, and target gender differences. The aspects of self were also analyzed.

The only other study to look at self-disclosure patterns of Black college students using the Jourard Self-Disclosure Questionnaire was done by Singleton (1976). She examined gender differences, target differences, racial subgroup differences, and aspects of self. She did not find a significant gender difference, nor did she find a difference in selfdisclosure rates based on racial self-designation. She did, however, find a target person difference. Black students preferred to self-disclose to a Black target person at a significantly greater rate than to White target persons. She also found a significant difference in rates of disclosure of various topics. Black students preferred to self-disclose information about personality, money, and body to Black target persons to a greater degree than to White target persons. The study of this examiner expands Singleton's study by looking at examiner effects (examiners varied by race and gender) and environmental effects (predominantly Black college and 
predominantly White college). This is the first study of its kind to examine these variables in one study.

As in an earlier study (Singleton, 1976), a significant race difference was found in this investigation. The combined group of Black students reported more willingness to disclose to a Black target person than to a White target person. This finding is also consistent with other findings on race differences and self-disclosure (Vontress, 1969; Dimont \& Hellkamp, 1969; Jourard, et. al., 1958, 1971; Littlefield, 1974).

The main effect for target gender was also significant. The combined group of students reported more willingness to disclose to a female target person than to a male target person. These findings are also consistent with other findings on gender differences and self-disclosure (Jourard, 1958, 1971; Casciani, 1973; Dimond, 1979; Cosby, 1983).

The main effect for racial environment on campus was not significant. Students at a predominantly Black university did not report more willingness to disclose than students at a predominantly White university. The current finding is the first time to this author's knowledge that this variable has been used in an investigation of self-disclosure. It suggests that Black students who attend universities in a major urban city tend to be homogeneous in their self-disclosing behavior. It also suggest that the racial environment on campus is a complex phenomenon and the current study did not completely capture its impact on self-disclosing behavior. The main effect for race of the examiner was not significant; however, a target race $\mathrm{x}$ examiner race $\mathrm{x}$ examiner gender interaction was significant. This finding indicated that for all four combinations of Examiner Race and Examiner Gender (Black male examiner, Black female examiner, White male examiner, and White female examiner) more disclosure was made to Black target persons than to White target persons.

The main effect for gender of the examiner was not significant; however, a target. race $\mathrm{x}$ target gender $\mathrm{x}$ subject gender interaction was 
significant. The findings indicated that for all four combinations of target race and target gender (Black male target person, Black female target person, White male target person, and White female target person), more disclosures were made to Black target persons than to White target persons. For the subscales or topics of self-disclosure, the results obtained were somewhat similar to those found for total self-disclosure. Target race and target gender emerged as significant effects. For target gender, the findings were that subjects disclosed more when the target person was female than when the target person was male in areas of Attitudes, Personality, Body, and Tastes and Interests. For target race, subjects disclosed more when the target person was Black than when the target person was White in areas of Work, Money, Body, and Personality. Singleton (1978) who arrived at similar findings, argued that topics of body, money, and personality are more personal in nature than topics about work, attitudes and taste; and that Blacks prefer to disclose more personal information to other Blacks. A significant target race $\mathrm{x}$ examiner race interaction was also found. This finding indicated that when the examiner was Black, subjects self-disclosed more to Black target persons on topics of attitudes and tastes.

A significant interaction for target gender $\mathrm{x}$ target race was also found. The findings indicated that for all four combinations of target gender and target race (Black male target person, Black female target person, White male target person, and White female target person), more disclosure was made to Black target persons than to White target persons on topics of Attitudes and Money.

This investigation is one of the first, to the author's knowledge, to simultaneously test for self-disclosure across school environment differences, target person differences, examiner differences, and subjects gender differences. The significant findings of sex, by target person racial and gender differences, by examiners racial and gender differences are 
interesting in that the data substantiate some earlier findings and contribute to our understanding of self-disclosure patterns among these different groups.

\section{IMPLICATIONS AND FUTURE RESEARCH DIRECTIONS}

The most important implication that can be drawn from this study is that Black college students preferred a Black counselor to a greater extent than a White counselor, and a female counselor over a male counselor. Students also reported being more willing to disclose about certain topics to Black target persons to a greater extent than to White target persons. If interventions and counseling decisions are grounded in lack of disclosure from Black students to a White counselor, then the counseling process may not be very effective. Another important implication of the study is that it found that race of counselor is just as important to today's Black student as Singleton (1976) found it to be fourteen years ago. Nonetheless, Blacks are not a homogeneous group and a future study might look at within group differences of urban versus rural students, and married students versus non-married students. A future investigation might also explore if undergraduates differ from graduate students in their rates of disclosure to counselors varied by race and gender. Another study might look at students who have received counseling versus students who have not received counseling and how their rates of self-disclosure differ when examiners' race and gender are varied. 


\section{APPENDIX A}

QUESTIONNAIRE

To The Participant:

You are participating in an investigation of the area of self-concept. Your participation is voluntary and all of the data collected in this experiment will be kept confidential.

If you wish to receive a copy of the findings of the study, please leave your name and address with the administrator of the material and a copy of the completed study will be sent to you. Do not write your name on any of the material given to you.

\section{DIRECTIONS:}

The answer sheet which you have been given has columns with the headings: Black Male, Age 30; White Male, Age 30; Black Female, Age 30; and White Female, Age 30. You are to read each item on the questionnaire, and then indicate on the answer sheet the extent to which you are willing to talk about that item to each person; that is, the extent to which you would make yourself known to that person. Use the rating scale listed below to rank the extent that you are willing to talk about each item to each target person.

\section{RATING SCALE:}

1. Will lie or misrepresent myself.

2. Will disclose nothing about this aspect of myself.

3. Will talk very little about this area.

4. Will talk in general terms about this aspect of myself.

5. Will disclose quite a bit about this area.

6. Will disclose fully on this topic. 


\begin{tabular}{|c|c|c|c|c|}
\hline \multicolumn{5}{|c|}{ ANSWER SHEET } \\
\hline ATTITUDES AND OPINIONS & \begin{tabular}{|l|} 
BLACK \\
MALE, \\
AGE 30 \\
\end{tabular} & \begin{tabular}{|l|} 
WHITE \\
MALE, \\
AGE 30
\end{tabular} & $\begin{array}{l}\text { BLACK } \\
\text { FEMALE, } \\
\text { AGE } 30\end{array}$ & \begin{tabular}{|l|} 
WHITE \\
FEMALE, \\
AGE 30 \\
\end{tabular} \\
\hline $\begin{array}{l}\text { 1. What I think and feel about } \\
\text { religion; my personal } \\
\text { religious views. }\end{array}$ & & & & \\
\hline $\begin{array}{l}\text { 2. My personal opinions and } \\
\text { feelings about other } \\
\text { religious groups than my } \\
\text { own, e.g. Protestants, } \\
\text { Catholics, Jews, atheist. }\end{array}$ & & & & \\
\hline 3. My views on communism. & & & & \\
\hline $\begin{array}{l}\text { 4. My views on the present } \\
\text { government - the president, } \\
\text { government policies, etc. }\end{array}$ & & & & \\
\hline $\begin{array}{l}\text { 5. My views on the question of } \\
\text { racial integration in } \\
\text { schools, transportation, } \\
\text { etc. }\end{array}$ & & & & \\
\hline $\begin{array}{l}\text { 6. My personal views on } \\
\text { drinking. }\end{array}$ & & & & \\
\hline $\begin{array}{l}\text { 7. My personal views on sexual } \\
\text { morality -- how I feel that } \\
\text { I and others ought to behave } \\
\text { in sexual matters. }\end{array}$ & & & & \\
\hline $\begin{array}{l}\text { 8. My personal standards of } \\
\text { beauty and attractiveness } \\
\text { in women - what I consider } \\
\text { to be attractive in a woman. }\end{array}$ & & & & \\
\hline $\begin{array}{l}\text { 9. The things that I regard as } \\
\text { desirable for a man to be - } \\
\text { what I look for in a man. }\end{array}$ & & & & \\
\hline $\begin{array}{l}\text { 10. My feelings about how } \\
\text { parents ought to deal with } \\
\text { children. }\end{array}$ & & & & \\
\hline
\end{tabular}




\begin{tabular}{|c|c|c|c|c|}
\hline \multicolumn{5}{|c|}{ ANSWER SHEET } \\
\hline FOODS - TASTES \& INTERESTS & $\begin{array}{l}\text { BLACK } \\
\text { MALE } \\
\text { AGE } 30\end{array}$ & $\begin{array}{l}\text { WHTE } \\
\text { MALE } \\
\text { AGE } 30\end{array}$ & $\begin{array}{l}\text { BLACK } \\
\text { FEMALE, } \\
\text { AGE } 30\end{array}$ & $\begin{array}{l}\text { WHTTE } \\
\text { FEMALE, } \\
\text { AGE } 30\end{array}$ \\
\hline $\begin{array}{l}\text { 1. My favorite foods, the way } \\
\text { I like food prepared, and } \\
\text { my food dislikes. }\end{array}$ & & & & \\
\hline $\begin{array}{l}\text { 2. My favorite beverages, and } \\
\text { the ones I don't like. }\end{array}$ & & & & \\
\hline $\begin{array}{l}\text { 3. My likes and dislikes in } \\
\text { music. }\end{array}$ & & & & \\
\hline 4. My favorite reading matter & & & & \\
\hline $\begin{array}{l}\text { 5. The kinds of movies I like } \\
\text { to see best; the TV shows } \\
\text { that are my favorite. }\end{array}$ & & & & \\
\hline 6. My tastes in clothing. & & & & \\
\hline $\begin{array}{l}\text { 7. The style of house, and the } \\
\text { kinds of furnishings I like } \\
\text { best. }\end{array}$ & & & & \\
\hline $\begin{array}{l}\text { 8. The kinds of parties or } \\
\text { social gatherings I like } \\
\text { best, and the kinds that } \\
\text { would bore me, or that I } \\
\text { wouldn't enjoy. }\end{array}$ & & & & \\
\hline $\begin{array}{l}9 \text { My favorite ways of } \\
\text { spending spare time, e.g., } \\
\text { hunting, reading, cards, } \\
\text { sporting events, parties, } \\
\text { dancing, etc.. }\end{array}$ & & & & \\
\hline $\begin{array}{l}\text { 10. What I would appreciate } \\
\text { most for a present. }\end{array}$ & & & & \\
\hline
\end{tabular}




\begin{tabular}{|c|c|c|c|c|}
\hline \multicolumn{5}{|c|}{ ANSWER SHEET } \\
\hline WORK (OR STUDIES) & $\begin{array}{l}\text { BLACK } \\
\text { MALE, } \\
\text { AGE } 30\end{array}$ & \begin{tabular}{|l} 
WHITE \\
MALE, \\
AGE 30
\end{tabular} & $\begin{array}{l}\text { BLACK } \\
\text { FEMALE, } \\
\text { AGE } 30\end{array}$ & $\begin{array}{l}\text { WHITE } \\
\text { FEMALE, } \\
\text { AGE } 30 \\
\end{array}$ \\
\hline $\begin{array}{l}\text { 1. What I find to be the worst } \\
\text { pressures and strains in } \\
\text { my work. }\end{array}$ & & & & \\
\hline $\begin{array}{l}\text { 2. What I find to be the most } \\
\text { boring and unenjoyable } \\
\text { aspects of my work. }\end{array}$ & & & & \\
\hline $\begin{array}{l}\text { 3. What I enjoy most, and get } \\
\text { the most satisfaction from } \\
\text { in my present work. }\end{array}$ & & & & \\
\hline $\begin{array}{l}\text { 4. What I feel are my short- } \\
\text { comings and handicaps that } \\
\text { prevent me from working } \\
\text { as I would like to, or that } \\
\text { prevent me from getting } \\
\text { further in my work. }\end{array}$ & & & & \\
\hline $\begin{array}{l}\text { 5. What I feel are my special } \\
\text { strong points and qualifi- } \\
\text { cations for my work. }\end{array}$ & & & & \\
\hline $\begin{array}{l}\text { 6. How I feel my work is } \\
\text { appreciated by others (e.g., } \\
\text { boss, fellow workers, } \\
\text { teacher, husband, etc. }\end{array}$ & & & & \\
\hline $\begin{array}{l}\text { 7. My ambitions and goals in } \\
\text { my work. }\end{array}$ & & & & \\
\hline $\begin{array}{l}\text { 8. My feelings about the } \\
\text { salary or rewards that I } \\
\text { get for my work. }\end{array}$ & & & & \\
\hline $\begin{array}{l}\text { 9. How I feel about the choice } \\
\text { of career I have made - } \\
\text { whether or not I am } \\
\text { satisfied with it. }\end{array}$ & & & & \\
\hline $\begin{array}{l}\text { 10.How I really feel about the } \\
\text { people that I work for, or } \\
\text { work with. }\end{array}$ & & & & \\
\hline
\end{tabular}




\begin{tabular}{|l|l|l|l|l|}
\hline \multicolumn{3}{|c|}{ ANSWER SHEET } \\
\hline MONEY & $\begin{array}{l}\text { BLACK } \\
\text { MALE, } \\
\text { AGE 30 }\end{array}$ & $\begin{array}{l}\text { WHITE } \\
\text { MALE, } \\
\text { AGE 30 }\end{array}$ & $\begin{array}{l}\text { BLACK } \\
\text { FEMAL, }\end{array}$ & $\begin{array}{l}\text { WHITE } \\
\text { FEMALE, } \\
\text { AGE 30 }\end{array}$ \\
\hline $\begin{array}{l}\text { 1. How much money I make at } \\
\text { my work, or get as an } \\
\text { allowance. }\end{array}$ & & & & \\
\hline $\begin{array}{l}\text { 2. Whether or not I owe } \\
\text { money; if so, how much. }\end{array}$ & & & & \\
\hline $\begin{array}{l}\text { 3. Whom I owe money to at } \\
\text { present; or whom I have } \\
\text { borrowed from in the past. }\end{array}$ & & & & \\
\hline $\begin{array}{l}\text { 4. Whether or not I have } \\
\text { savings, and the amount. }\end{array}$ & & & & \\
\hline $\begin{array}{l}\text { 5. Whether or not others owe } \\
\text { me money; the amount, and } \\
\text { who owes it to me. }\end{array}$ & & & & \\
\hline $\begin{array}{l}\text { 6. Whether or not I gamble; if } \\
\text { so, the way I gamble, and } \\
\text { the extent of it. }\end{array}$ & & & & \\
\hline $\begin{array}{l}\text { 7. All of my present sources } \\
\text { of income - wage, fees, } \\
\text { allowances, dividends, etc. }\end{array}$ & & & & \\
\hline $\begin{array}{l}\text { 8. My total financial worth, } \\
\text { including property, } \\
\text { savings, bonds, insurance, } \\
\text { etc. }\end{array}$ & & & & \\
\hline $\begin{array}{l}\text { 9. My most pressing need for } \\
\text { money right now, e.g., } \\
\text { outstanding bills, some } \\
\text { major purchase that is } \\
\text { desired or needed. }\end{array}$ & & & \\
\hline $\begin{array}{l}\text { 10. How I budget my money - } \\
\text { the proportions that go to } \\
\text { necessities, luxuries, etc. }\end{array}$ & & & \\
\hline
\end{tabular}




\begin{tabular}{|c|c|c|c|c|}
\hline \multicolumn{5}{|c|}{ ANSWER SHEET } \\
\hline PERSONALITY & $\begin{array}{l}\text { BLACK } \\
\text { MALE, } \\
\text { AGE 30 }\end{array}$ & $\begin{array}{l}\text { WHITE } \\
\text { MALE, } \\
\text { AGE 30 }\end{array}$ & $\begin{array}{l}\text { BLACK } \\
\text { FEMALE, } \\
\text { AGE } 30\end{array}$ & $\begin{array}{l}\text { WHITE } \\
\text { FEMALE, } \\
\text { AGE 30 }\end{array}$ \\
\hline $\begin{array}{l}\text { 1. The aspects of my personality } \\
\text { that I dislike, worry about, } \\
\text { that I regard as a handicap to } \\
\text { me. }\end{array}$ & & & & \\
\hline $\begin{array}{l}\text { 2. What feelings, if any, I have } \\
\text { trouble expressing or } \\
\text { controlling. }\end{array}$ & & & & \\
\hline $\begin{array}{l}\text { 3. The facts of my present sex } \\
\text { life - including knowledge of } \\
\text { how I get sexual } \\
\text { gratification; any problems I } \\
\text { might have, with whom I have } \\
\text { relations, if anybody. }\end{array}$ & & & & \\
\hline $\begin{array}{l}\text { 4. Whether or not I feel I am } \\
\text { attractive to the opposite } \\
\text { sex; my problems, if any, } \\
\text { about getting favorable } \\
\text { attention from the opposite } \\
\text { sex. }\end{array}$ & & & & \\
\hline $\begin{array}{l}\text { 5. Things in the past or present } \\
\text { that I feel ashamed of or } \\
\text { guilty about. }\end{array}$ & & & & \\
\hline $\begin{array}{l}\text { 6. The kinds of things that just } \\
\text { make me furious. }\end{array}$ & & & & \\
\hline $\begin{array}{l}\text { 7. What it takes to get me } \\
\text { feeling real depressed and } \\
\text { blue. }\end{array}$ & & & & \\
\hline $\begin{array}{l}\text { 8. What it takes to get me real } \\
\text { worried, anxious, and afraid. }\end{array}$ & & & & \\
\hline $\begin{array}{l}\text { 9. What it takes to hurt my } \\
\text { feelings deeply. }\end{array}$ & & & & \\
\hline $\begin{array}{l}\text { 10. The kinds of things that make } \\
\text { me especially proud of } \\
\text { myself, elated, full of self- } \\
\text { esteem or self-respect. }\end{array}$ & & & & \\
\hline
\end{tabular}




\begin{tabular}{|c|c|c|c|c|}
\hline \multicolumn{5}{|c|}{ ANSWER SHEET } \\
\hline BODY & $\begin{array}{l}\text { BLACK } \\
\text { MALE, } \\
\text { AGE } 30\end{array}$ & $\begin{array}{l}\text { WHITE } \\
\text { MALE, } \\
\text { AGE } 30\end{array}$ & $\begin{array}{l}\text { BLACK } \\
\text { FEMALE, } \\
\text { AGE } 30\end{array}$ & $\begin{array}{l}\text { WHITE } \\
\text { FEMALE, } \\
\text { AGE } 30\end{array}$ \\
\hline $\begin{array}{l}\text { 1. My feelings about the } \\
\text { appearance of my face - } \\
\text { things I don't like, and things } \\
\text { I might like about my face } \\
\text { and head - nose, eyes, hair, } \\
\text { teeth, etc. }\end{array}$ & & & & \\
\hline $\begin{array}{l}\text { 2. How I wish I looked; my } \\
\text { ideals for overall appearance. }\end{array}$ & & & & \\
\hline $\begin{array}{l}\text { 3. My feelings about different } \\
\text { parts of my body - legs, hips, } \\
\text { waist, height, chest, or bust, } \\
\text { etc. }\end{array}$ & & & & \\
\hline $\begin{array}{l}\text { 4. Any problems and worries I } \\
\text { had with my appearance in } \\
\text { the past. }\end{array}$ & & & & \\
\hline $\begin{array}{l}\text { 5. Whether or not I now have any } \\
\text { health problems, e.g., trouble } \\
\text { with sleep, digestion, female } \\
\text { complaints, heart condition, } \\
\text { allergies, headaches, piles, } \\
\text { etc. }\end{array}$ & & & & \\
\hline $\begin{array}{l}\text { 6. Whether or not I have any } \\
\text { long-range worries or } \\
\text { concerns about my health, } \\
\text { e.g., cancer, ulcers, heart } \\
\text { trouble. }\end{array}$ & & & & \\
\hline $\begin{array}{l}\text { 7. My past record of illness and } \\
\text { treatment. }\end{array}$ & & & & \\
\hline $\begin{array}{l}\text { 8. Whether or not I now make } \\
\text { special efforts to keep fit, } \\
\text { healthy, and attractive, e.g. } \\
\text { calistenics, diet. }\end{array}$ & & & & \\
\hline $\begin{array}{l}\text { 9. My present physical } \\
\text { measurements, e.g., height, } \\
\text { weight, waist, etc. }\end{array}$ & & & & \\
\hline $\begin{array}{l}\text { 10. My feelings about my } \\
\text { adequacy in sexual behavior - } \\
\text { whether or not I feel able to } \\
\text { perform adequately in sex } \\
\text { relationships. }\end{array}$ & & & & \\
\hline
\end{tabular}




\section{APPENDIX B}

\section{PERSONAL DATA SHEET}

Thank you for your participation in this study. All information and responses within this questionnaire are CONFIDENTIAL and will be used only for statistical purposes. Your name is not required. It will be very helpful if you would answer all items which apply to you.

SEX: Male

Female

Age

BIRTHDATE (Mo. Day Year)

BIRTHPLACE

RACE: (Please check the one term which best describes your preferred racial identification.)

Afro-American

Black

Colored

Negro

Other

(please list)

GRADE STATUS:

Freshman

Sophomore

Junior

Senior

MARITAL STATUS:

Single

Married

Divorced

Widowed Separated

FATHER'S OCCUPATION:

MOTHER'S OCCUPATION:

EDUCATION: (Please underline the HIGHEST grade level completed by your parents.)

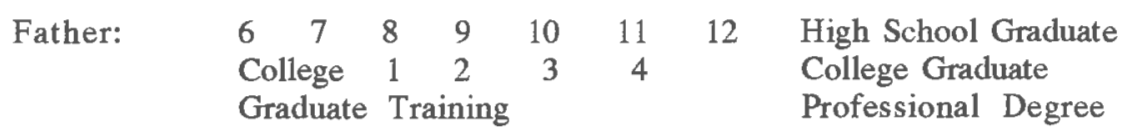

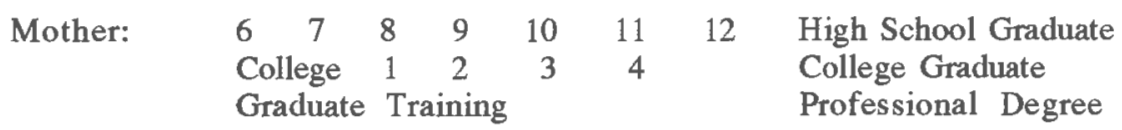


Appendix B

Personal Data Sheet (continued)

Have you had previous counseling?

Yes

No

Where: High School

College

Private Agency

Church

Camp

Other

By Whom: College Professor

College Counselor

Private Doctor

Social Worker

Minister

Other

How long did you receive counseling?

Once

Two to Five Times

Week(s)

Month(s)
Year(s)

Other

Please check the terms which describe the counselor you saw during your LONGEST counseling experience:
Black Male
White Male
Black Female
White Female
Other

The area of concern of my previous counseling was:

\begin{tabular}{|c|c|}
\hline Educational Skills & Vocational/Education \\
\hline $\begin{array}{l}\text { Personal Social } \\
\text { Other }\end{array}$ & All of the Above \\
\hline
\end{tabular}

If there was a choice of persons to whom you would presently go for counseling, which would you prefer:
Black Male
White Male
Black Female
White Female
Other 


\section{APPENDIX C}

\section{INFORMED CONSENT}

The purpose of this study is to measure the amount of interaction that takes place between yourself and four different potential target persons. The results of this study will give me information about how people perceive their interaction with other persons. This study is being completed in partial fulfillment of doctoral degree requirements, and the research results may be published. Your name will not be used in any reports of this data.

I have had this study explained to me and agree to participate. If I have any questions, I can call Stan Cosby at (202) 483-4923. 


\section{APPENDIX D}

ANOVA Summary on Attitudes and Opinions as a Topic of Self-Disclosure by Subject College, Subject Gender, Examiner Gender, Examiner Race, Target Gender and Target Race

\begin{tabular}{|c|c|c|c|}
\hline Source & in Square & df & $\mathbf{F}$ \\
\hline \multicolumn{4}{|l|}{ Between Subjects Effects } \\
\hline SSchool & 1.01 & 1 & 0.58 \\
\hline SGender & 3.60 & 1 & 2.08 \\
\hline SSchool x Gender & 0.31 & 1 & 0.18 \\
\hline ExRace & 0.37 & 1 & 0.21 \\
\hline SSchool x ExRace & 0.59 & 1 & 0.34 \\
\hline SGender $\mathrm{x}$ ExRace & 1.64 & 1 & 0.95 \\
\hline SSchool x SGender x ExRace & 0.85 & 1 & 0.49 \\
\hline ExGender & 4.68 & 1 & 2.70 \\
\hline SSchool x ExGender & 2.70 & 1 & 1.56 \\
\hline SGender x ExGender & 0.10 & 1 & 0.06 \\
\hline SSchool x SGender $\mathrm{x}$ ExGender & 3.80 & 1 & 2.20 \\
\hline ExRace x ExGender & 0.09 & 1 & 0.05 \\
\hline SSchool x ExRace x ExGender & 0.14 & 1 & 0.08 \\
\hline SGender x ExRace x ExGender & 0.70 & 1 & 0.40 \\
\hline $\begin{array}{l}\text { SSchool x SGender x ExRace x ExGender } \\
\text { ERROR }\end{array}$ & 1.735 & 224 & - \\
\hline \multicolumn{4}{|l|}{ Within Subject Effects } \\
\hline \multicolumn{4}{|l|}{ Involving Target Gender } \\
\hline TGender & 1.31 & 1 & $24.81 * *$ \\
\hline TGender x SSchool & 0.02 & 1 & 0.33 \\
\hline TGender $\times$ SGender & 3.36 & 1 & $63.44 * *$ \\
\hline TGender x SSchool x SGender & 0.00 & 1 & 0.00 \\
\hline TGender x ExRace & 0.08 & 1 & 1.47 \\
\hline TGender x SSchool x ExRace & 0.02 & 1 & 0.30 \\
\hline TGender x SGender x ExRace & 0.03 & 1 & 0.61 \\
\hline TGender x SSchool x SGender x ExRace & 0.08 & 1 & 1.62 \\
\hline TGender $x$ ExGender & 0.00 & 1 & 0.06 \\
\hline TGender x SSchool x ExGender & 0.18 & 1 & 3.33 \\
\hline TGender $x$ SGender $x$ ExGender & 0.01 & 1 & 0.16 \\
\hline TGender $x$ SSchool x SGender x ExGender & 0.02 & 1 & 0.43 \\
\hline TGender x ExRace x ExGender & 0.13 & 1 & 2.47 \\
\hline TGender $x$ SSchool $x$ ExRace $x$ ExGender & 0.16 & 1 & 3.03 \\
\hline TGender $x$ SGender $x$ ExRace $x$ ExGender & 0.05 & 1 & 0.90 \\
\hline \multicolumn{4}{|l|}{ TGender $\mathrm{x}$ SSchool $\mathrm{x}$ SGender $\mathrm{x}$ ExRace } \\
\hline x ExGender & 0.13 & 1 & 2.55 \\
\hline ERROR (TGender) & 0.54 & 224 & -- \\
\hline
\end{tabular}




\begin{tabular}{|c|c|c|c|}
\hline Source & Mean Square & df & F \\
\hline \multicolumn{4}{|l|}{ Within Subject Effects } \\
\hline \multicolumn{4}{|l|}{ Involving Target Race } \\
\hline TRace & 88.45 & 1 & $248.04 * *$ \\
\hline TRace x SSchool & 0.06 & 1 & 0.16 \\
\hline TRace $x$ SGender & 0.37 & 1 & 1.04 \\
\hline TRace x SSchool x SGender & 0.22 & 1 & 0.62 \\
\hline TRace $x$ ExRace & 7.03 & 1 & $19.70 * *$ \\
\hline TRace x SSchool x ExRace & 0.40 & 1 & 1.15 \\
\hline TRace x SGender x ExRace & 0.34 & 1 & 0.96 \\
\hline TRace x SSchool x SGender x ExRace & 0.00 & 1 & 0.01 \\
\hline TRace $x$ ExGender & 2.69 & 1 & 7.53 \\
\hline TRace x SSchool x ExGender & 0.03 & 1 & 0.09 \\
\hline TRace x SGender x ExGender & 2.61 & 1 & 7.32 \\
\hline TRace $x$ SSchool x SGender $x$ ExGender & 0.57 & 1 & 1.59 \\
\hline TRace x ExRace x ExGender & 2.72 & 1 & $7.61 *$ \\
\hline TRace x SSchool x ExRace x ExGender & 1.20 & 1 & 3.35 \\
\hline TRace $x$ SGender $x$ ExRace $x$ ExGender & 0.15 & 1 & 0.41 \\
\hline \multicolumn{4}{|l|}{ TRace x SSchool x SGender x ExRace } \\
\hline $\mathrm{x}$ ExGender & 0.64 & 1 & 1.79 \\
\hline ERROR (TRace) & 0.357 & 224 & - \\
\hline \multicolumn{4}{|l|}{ Within Subject Effects } \\
\hline \multicolumn{4}{|l|}{ Involving Target Gender $\times$ Target Race } \\
\hline TGender $\mathrm{x}$ TRace & 0.04 & 1 & 1.46 \\
\hline TGender $\times$ TRace $\times$ SSchool & 0.00 & 1 & 0.00 \\
\hline TGender $\mathrm{x}$ TRace $\mathrm{x}$ SGender & 0.34 & 1 & $11.80 * *$ \\
\hline TGender $\mathrm{x}$ TRace $\mathrm{x}$ SSchool $\mathrm{x}$ SGender & 0.03 & 1 & 1.02 \\
\hline TGender $x$ TRace $x$ ExRace & 0.00 & 1 & 0.03 \\
\hline TGender x TRace x SSchool x ExRace & 0.01 & 1 & 0.41 \\
\hline TGender $x$ TRace $x$ SGender x ExRace & 0.08 & 1 & 2.88 \\
\hline \multicolumn{4}{|l|}{ TGender $x$ TRace $x$ SSchool $x$ SGender } \\
\hline $\mathrm{x}$ ExRace & 0.00 & 1 & 0.01 \\
\hline TGender x TRace x ExGender & 0.00 & 1 & 0.01 \\
\hline TGender $x$ TRace $x$ SSchool $x$ ExGender & 0.01 & 1 & 0.25 \\
\hline TGender $x$ TRace $x$ SGender $x$ ExGender & 0.00 & 1 & 0.10 \\
\hline \multicolumn{4}{|l|}{ TGender $x$ TRace $x$ SSchool x SGender } \\
\hline ExGender & 0.00 & 1 & 0.16 \\
\hline TGender $x$ TRace $x$ ExRace $x$ ExGender & 0.02 & 1 & 0.67 \\
\hline \multicolumn{4}{|l|}{ TGender $x$ TRace $x$ SSchool $x$ ExRace } \\
\hline x ExGender & 0.14 & 1 & 4.85 \\
\hline \multicolumn{4}{|l|}{ TGender x TRace x SGender x ExRace } \\
\hline $\mathrm{x}$ ExGender & 0.01 & 1 & 0.30 \\
\hline \multicolumn{4}{|l|}{ TGender $\times$ TRace $\times$ SSchool $x$ SGender } \\
\hline $\mathrm{x}$ ExRace $\mathrm{x}$ ExGender & 0.00 & 1 & 0.01 \\
\hline ERROR (TGender x TRace) & 0.029 & 224 & - - \\
\hline
\end{tabular}

$*_{\mathrm{p}}<.001$ (following a significant Multivariate $\mathrm{F}$ )

${ }^{* *} \mathrm{p}<.0001$ (following a significant Multivariate F) 


\section{APPENDIX E}

ANOVA Summary on Tastes and Interests as a Topic of Self-Disclosure by Subject College, Subject Gender, Examiner Gender, Examiner Race, Target Gender and Target Race

Source

\section{Between Subjects Effects}

SSchool

SGender

SSchool x SGender

ExRace

SSchool x ExRace

SGender $x$ ExRace

SSchool x SGender $x$ ExRace

ExGender

SSchool $x$ ExGender

SGender $x$ ExGender

SSchool $x$ SGender $x$ ExGender

ExRace $x$ ExGender

SSchool x ExRace x ExGender

SGender $x$ ExRace $x$ ExGender

SSchool x SGender x ExRace x ExGender

ERROR

Within Subject Effects

Involving Target Gender

TGender

TGender $x$ SSchool

TGender $x$ SGender

TGender $x$ SSchool $x$ SGender

TGender $x$ ExRace

TGender $x$ SSchool $x$ ExRace

TGender $x$ SGender $x$ ExRace

TGender $x$ SSchool $x$ SGender $x$ ExRace

TGender $x$ ExGender

TGender $x$ SSchool $x$ ExGender

TGender $x$ SGender $x$ ExGender

TGender $x$ SSchool $x$ SGender $x$ ExGender

TGender $x$ ExRace $x$ ExGender

TGender $x$ SSchool $x$ ExRace $x$ ExGender

TGender $x$ SGender $x$ ExRace $x$ ExGender

TGender $x$ SSchool $x$ SGender $x$ ExRace

$$
x \text { ExGender }
$$

ERROR (TGender)

\subsection{1}

5.04

2.36

0.60

4.85

0.90

0.48

3.17

5.00

0.00

4.80

0.56

3.95

11.28

10.83

2.384
0.17

2.12

0.99

0.25

2.03

0.38

0.20

1.33

2.10

0.00

2.01

0.24

1.66

4.73

4.57

224

- -
2.37

0.01

0.02

0.08

0.01

0.01

0.50

0.02

0.41

0.00

0.00

0.01

0.09

0.02

0.02

0.02

0.102
1

1

1

1

1

1

1

1

1

1

1

1

1

1

224

$23.13 * *$
0.18
0.22
0.72
0.13
0.13
4.93
0.17
3.97
0.00
0.01
0.13
0.86
0.19
0.22
0.21
.-

$23.13 * *$

0.72

0.13

0.13

4.93

0.17

3.97

0.01

0.13

0.86

0.19

0.21 


\begin{tabular}{|c|c|c|c|}
\hline Source & an Square & $\mathrm{df}$ & $\bar{F}$ \\
\hline \multicolumn{4}{|l|}{ Within Subject Effects } \\
\hline \multicolumn{4}{|l|}{ Involving Target Race } \\
\hline TRace & 51.21 & 1 & $108.85 * *$ \\
\hline TRace $\times$ SSchool & 1.55 & 1 & 3.18 \\
\hline TRace $\mathrm{x}$ SGender & 0.32 & 1 & 0.66 \\
\hline TRace x SSchool x SGender & 0.02 & 1 & 0.04 \\
\hline TRace $x$ ExRace & 7.87 & 1 & $16.09 * *$ \\
\hline TRace x SSchool x ExRace & 0.02 & 1 & 0.04 \\
\hline TRace x SGender x ExRace & 1.12 & 1 & 2.30 \\
\hline TRace x SSchool x SGender x ExRace & 1.83 & 1 & 3.74 \\
\hline TRace $\mathrm{x}$ ExGender & 0.34 & 1 & 0.69 \\
\hline TRace x SSchool x ExGender & 0.66 & 1 & 1.36 \\
\hline TRace $\mathrm{x}$ SGender $\mathrm{x}$ ExGender & 1.58 & 1 & 3.22 \\
\hline TRace x SSchool x SGender x ExGender & 1.82 & 1 & 3.72 \\
\hline TRace $\mathrm{x}$ ExRace $\mathrm{x}$ ExGender & 1.53 & 1 & 3.14 \\
\hline TRace x SSchool x ExRace x ExGender & 0.84 & 1 & 1.71 \\
\hline TRace $x$ SGender $x$ ExRace $x$ ExGender & 0.30 & 1 & 0.61 \\
\hline \multicolumn{4}{|l|}{ TRace x SSchool x SGender x ExRace } \\
\hline $\mathrm{x}$ ExGender & 0.92 & 1 & 1.89 \\
\hline ERROR (TRace) & 0.357 & 224 & -- \\
\hline \multicolumn{4}{|l|}{ Within Subject Effects } \\
\hline \multicolumn{4}{|l|}{ Involving Target Gender $\mathrm{x}$ Target Race } \\
\hline TGender $x$ TRace & 0.00 & 1 & 0.00 \\
\hline TGender $x$ TRace $x$ SSchool & 0.00 & 1 & 0.06 \\
\hline TGender $x$ TRace $x$ SGender & 0.11 & 1 & 4.59 \\
\hline TGender $\times$ TRace $\times$ SSchool $\times$ SGender & 0.00 & 1 & 1.42 \\
\hline TGender $x$ TRace $x$ ExRace & 0.01 & 1 & 0.22 \\
\hline TGender $x$ TRace $x$ SSchool $x$ ExRace & 0.13 & 1 & 5.26 \\
\hline TGender $\mathrm{x}$ TRace $\mathrm{x}$ SGender $\mathrm{x}$ ExRace & 0.00 & 1 & 0.77 \\
\hline TGender $\mathrm{x}$ TRace $\mathrm{x}$ SSchool $\mathrm{x}$ SGender & & 1 & \\
\hline $\mathrm{x}$ ExRace & 0.02 & 1 & 0.65 \\
\hline TGender $x$ TRace $x$ ExGender & 0.08 & 1 & 3.50 \\
\hline TGender $\mathrm{x}$ TRace $\mathrm{x}$ SSchool $\mathrm{x}$ ExGender & 0.01 & 1 & 0.38 \\
\hline TGender $x$ TRace $x$ SGender $x$ ExGender & 0.01 & 1 & 0.37 \\
\hline \multicolumn{4}{|l|}{ TGender $x$ TRace $x$ SSchool $x$ SGender } \\
\hline ExGender & 0.01 & 1 & 0.22 \\
\hline TGender $x$ TRace $x$ ExRace $x$ ExGender & 0.00 & 1 & 0.07 \\
\hline \multicolumn{4}{|l|}{ TGender x TRace x SSchool x ExRace } \\
\hline$x$ ExGender & 0.05 & 1 & 2.04 \\
\hline \multicolumn{4}{|l|}{ TGender $x$ TRace $x$ SGender $x$ ExRace } \\
\hline $\mathrm{x}$ ExGender & 0.08 & 1 & 3.26 \\
\hline \multicolumn{4}{|l|}{ TGender x TRace x SSchool x SGender } \\
\hline $\mathrm{x}$ ExRace $\mathrm{x}$ ExGender & 0.03 & 1 & 1.44 \\
\hline ERROR (TGender x TRace) & 0.024 & 224 & -- \\
\hline
\end{tabular}

${ }_{\mathrm{p}}^{\mathrm{p}}<.001$ (following a significant Multivariate $\mathrm{F}$ )

${ }^{*} \mathrm{p}<.0001$ (following a significant Multivariate F) 


\section{APPENDIX F}

ANOVA Summary on Work or Studies as a Topic of Self-Disclosure by Subject College, Subject Gender, Examiner Gender, Examiner Race, Target Gender and Target Race

\begin{tabular}{|c|c|c|c|}
\hline Source & n Square & df & $F$ \\
\hline \multicolumn{4}{|l|}{ Between Subjects Effects } \\
\hline $\begin{array}{l}\text { SSchool } \\
\text { SGender } \\
\text { SSchool x SGender } \\
\text { ExRace } \\
\text { SSchool x ExRace } \\
\text { SGender x ExRace } \\
\text { SSchool x SGender x ExRace } \\
\text { ExGender } \\
\text { SSchool x ExGender } \\
\text { SGender x ExGender } \\
\text { SSchool x SGender x ExGender } \\
\text { ExRace x ExGender } \\
\text { SSchool x ExRace x ExGender } \\
\text { SGender x ExRace x ExGender } \\
\text { SSchool x SGender x ExRace x ExGender } \\
\text { ERROR }\end{array}$ & $\begin{array}{l}4.94 \\
2.20 \\
4.58 \\
1.20 \\
1.09 \\
2.29 \\
5.93 \\
4.01 \\
0.22 \\
3.52 \\
9.74 \\
1.04 \\
2.29 \\
5.73 \\
0.06 \\
2.764\end{array}$ & $\begin{array}{l}1 \\
1 \\
1 \\
1 \\
1 \\
1 \\
1 \\
1 \\
1 \\
1 \\
1 \\
1 \\
1 \\
1 \\
1 \\
224\end{array}$ & $\begin{array}{l}1.79 \\
0.80 \\
1.66 \\
0.44 \\
0.40 \\
0.83 \\
2.15 \\
1.46 \\
0.08 \\
1.28 \\
3.54 \\
0.38 \\
0.83 \\
2.08 \\
0.02 \\
-.-\end{array}$ \\
\hline \multicolumn{4}{|l|}{$\begin{array}{l}\text { Within Subject Effects } \\
\text { Involving Target Gender }\end{array}$} \\
\hline 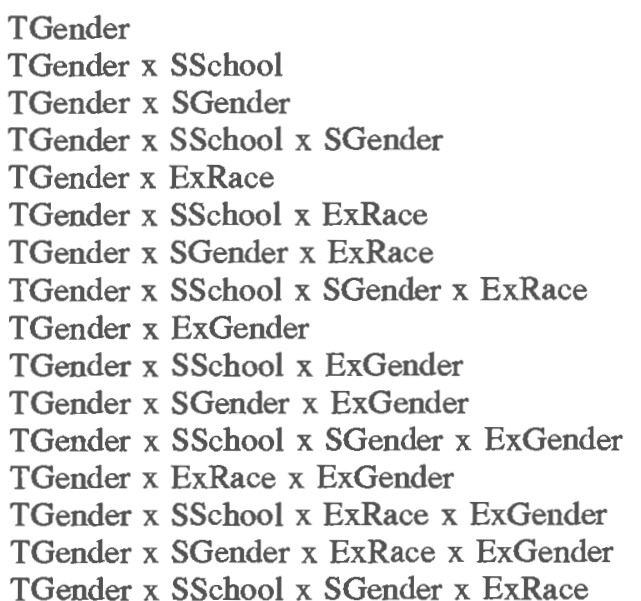 & $\begin{array}{l}0.63 \\
0.15 \\
1.40 \\
0.08 \\
0.26 \\
0.00 \\
0.13 \\
0.02 \\
0.08 \\
0.03 \\
0.22 \\
0.36 \\
0.00 \\
0.02 \\
0.00\end{array}$ & $\begin{array}{l}1 \\
1 \\
1 \\
1 \\
1 \\
1 \\
1 \\
1 \\
1 \\
1 \\
1 \\
1 \\
1 \\
1 \\
1\end{array}$ & $\begin{array}{l}6.11 \\
1.46 \\
13.69 * * \\
0.02 \\
2.52 \\
0.00 \\
1.23 \\
0.16 \\
0.76 \\
0.24 \\
2.11 \\
3.48 \\
0.04 \\
0.22 \\
0.00\end{array}$ \\
\hline $\begin{array}{c}\text { x ExGender } \\
\text { ERROR (TGender) }\end{array}$ & $\begin{array}{l}0.03 \\
0.03\end{array}$ & $\begin{array}{c}1 \\
224\end{array}$ & $\begin{array}{c}0.28 \\
-\end{array}$ \\
\hline
\end{tabular}




\begin{tabular}{|c|c|c|c|}
\hline Source & Mean Square & $\mathrm{df}$ & $\mathrm{F}$ \\
\hline \multicolumn{4}{|l|}{ Within Subject Effects } \\
\hline \multicolumn{4}{|l|}{ Involving Target Race } \\
\hline TRace & 100.28 & 1 & $184.77 * *$ \\
\hline TRace $x$ SSchool & 0.03 & 1 & 0.05 \\
\hline TRace x SGender & 0.17 & 1 & 0.31 \\
\hline TRace x SSchool x SGender & 0.27 & 1 & 0.50 \\
\hline TRace $x$ ExRace & 6.87 & 1 & $12.66 *$ \\
\hline TRace x SSchool x ExRace & 0.29 & 1 & 0.53 \\
\hline TRace $x$ SGender $x$ ExRace & 3.11 & 1 & 5.73 \\
\hline TRace $\times$ SSchool x SGender $\times$ ExRace & 0.09 & 1 & 0.16 \\
\hline TRace x ExGender & 0.44 & 1 & 0.81 \\
\hline TRace $\times$ SSchool x ExGender & 0.11 & 1 & 0.20 \\
\hline TRace x SGender x ExGender & 0.06 & 1 & 0.12 \\
\hline TRace $x$ SSchool x SGender $x$ ExGender & 0.66 & 1 & 1.22 \\
\hline TRace $x$ ExRace x ExGender & 4.94 & 1 & 9.10 \\
\hline TRace x SSchool x ExRace $x$ ExGender & 0.00 & 1 & 0.01 \\
\hline TRace x SGender x ExRace $x$ ExGender & 0.13 & 1 & 0.24 \\
\hline \multicolumn{4}{|l|}{ TRace x SSchool x SGender x ExRace } \\
\hline x ExGender & 0.10 & 1 & 0.18 \\
\hline ERROR (TRace) & 0.543 & 224 & - \\
\hline \multicolumn{4}{|l|}{ Within Subject Effects } \\
\hline \multicolumn{4}{|l|}{ Involving Target Gender $\times$ Target Race } \\
\hline TGender $x$ TRace & 0.09 & 1 & 1.76 \\
\hline TGender $\mathrm{x}$ TRace $\mathrm{x}$ SSchool & 0.16 & 1 & 3.10 \\
\hline TGender $\mathrm{x}$ TRace $\mathrm{x}$ SGender & 0.23 & 1 & 4.37 \\
\hline TGender $\times$ TRace $\times$ SSchool $\times$ SGender & 0.01 & 1 & 0.18 \\
\hline TGender $\mathrm{x}$ TRace $\mathrm{x}$ ExRace & 0.31 & 1 & 5.94 \\
\hline TGender $x$ TRace x SSchool x ExRace & 0.01 & 1 & 0.23 \\
\hline TGender $x$ TRace $x$ SGender $x$ ExRace & 0.11 & 1 & 2.04 \\
\hline \multicolumn{4}{|l|}{ TGender $\times$ TRace $\times$ SSchool x SGender } \\
\hline $\mathrm{x}$ ExRace & 0.04 & 1 & 0.71 \\
\hline TGender $x$ TRace $x$ ExGender & 0.10 & 1 & 1.90 \\
\hline TGender $x$ TRace $x$ SSchool $x$ ExGender & 0.00 & 1 & 0.03 \\
\hline TGender $x$ TRace $x$ SGender $x$ ExGender & 0.23 & 1 & 4.38 \\
\hline \multicolumn{4}{|l|}{ TGender x TRace x SSchool x SGender } \\
\hline ExGender & 0.03 & 1 & 0.55 \\
\hline TGender $x$ TRace $x$ ExRace $x$ ExGender & 0.05 & 1 & 1.01 \\
\hline \multicolumn{4}{|l|}{ TGender x TRace X SSchool x ExRace } \\
\hline x ExGender & 0.01 & 1 & 0.10 \\
\hline \multicolumn{4}{|l|}{ TGender $x$ TRace $x$ SGender $x$ ExRace } \\
\hline \multirow{2}{*}{\multicolumn{4}{|c|}{ TGender x TRace $\times$ SSchool x SGender }} \\
\hline & & & \\
\hline x ExRace x ExGender & 0.05 & 1 & 1.00 \\
\hline ERROR (TGender x TRace) & 0.052 & 224 & - - \\
\hline
\end{tabular}




\section{APPENDIX G}

ANOVA Summary on Money as a Topic of

Self-Disclosure by Subject College, Subject Gender, Examiner Gender, Examiner Race, Target Gender and Target Race

Source

\section{Between Subjects Effects}

SSchool

SGender

SSchool x SGender

ExRace

SSchool $x$ ExRace

SGender $x$ ExRace

SSchool x SGender $x$ ExRace

ExGender

SSchool x ExGender

SGender $x$ ExGender

SSchool x SGender $x$ ExGender

ExRace $x$ ExGender

SSchool $x$ ExRace $x$ ExGender

SGender $x$ ExRace $x$ ExGender

SSchool $x$ SGender $x$ ExRace $x$ ExGender

ERROR

Within Subject Effects

Involving Target Gender

TGender

0.03

0.00

TGender $x$ SSchool

2.54

TGender $x$ SGender

0.14

TGender $x$ SSchool x SGender

TGender $x$ ExRace

0.05

0.38

0.00

TGender $x$ SGender $x$ ExRace

0.02

0.08

0.03

0.00

0.37

0.07

0.01

0.03

0.04

0.065

TGender $x$ SSchool $x$ SGender $x$ ExRace $x$ ExGender

ERROR (TGender)
1.30

2.76

0.20

0.36

1.97

1.80

0.27

0.05

0.28

0.20

0.30

1.86

0.28

2.60

1.09

224

-.

0.44

0.02

$38.93 * *$

2.20

0.78

5.86

0.00

0.25

1.21

0.39

0.01

5.59

1.07

0.24

0.53

0.55 


\begin{tabular}{|c|c|c|c|}
\hline Source & Mean Square & $\mathrm{df}$ & $\mathrm{F}$ \\
\hline \multicolumn{4}{|l|}{ Within Subject Effects } \\
\hline \multicolumn{4}{|l|}{ Involving Target Race } \\
\hline TRace & 31.83 & 1 & $100.90 * *$ \\
\hline TRace x SSchool & 0.29 & 1 & 0.92 \\
\hline TRace $x$ SGender & 0.36 & 1 & 1.14 \\
\hline TRace x SSchool x SGender & 0.12 & 1 & 0.39 \\
\hline TRace $x$ ExRace & 0.03 & 1 & 0.08 \\
\hline TRace x SSchool x ExRace & 0.01 & 1 & 0.02 \\
\hline TRace x SGender x ExRace & 4.69 & 1 & 14.86 \\
\hline TRace x SSchool x SGender x ExRace & 0.00 & 1 & 0.00 \\
\hline TRace x ExGender & 0.00 & 1 & 0.01 \\
\hline TRace x SSchool x ExGender & 0.34 & 1 & 1.08 \\
\hline TRace x SGender x ExGender & 0.08 & 1 & 0.24 \\
\hline TRace x SSchool x SGender x ExGender & 0.19 & 1 & 0.61 \\
\hline TRace x ExRace x ExGender & 0.07 & 1 & 6.55 \\
\hline TRace x SSchool x ExRace x ExGender & 0.35 & 1 & 1.10 \\
\hline TRace $x$ SGender $x$ ExRace $x$ ExGender & 0.04 & 1 & 0.14 \\
\hline \multicolumn{4}{|l|}{ TRace $x$ SSchool x SGender x ExRace } \\
\hline x ExGender & 1.43 & 1 & 4.52 \\
\hline ERROR (TRace) & 0.315 & 224 & -- \\
\hline \multicolumn{4}{|l|}{ Within Subject Effects } \\
\hline \multicolumn{4}{|l|}{ Involving Target Gender $\times$ Target Race } \\
\hline TGender $\times$ TRace & 0.00 & 1 & 0.12 \\
\hline TGender $x$ TRace $x$ SSchool & 0.01 & 1 & 0.37 \\
\hline TGender $x$ TRace $x$ SGender & 1.08 & 1 & $27.21 * *$ \\
\hline TGender $\mathrm{x}$ TRace $\mathrm{x}$ SSchool $\mathrm{x}$ SGender & 0.15 & 1 & 3.72 \\
\hline TGender $x$ TRace $x$ ExRace & 0.42 & 1 & 10.50 \\
\hline TGender x TRace x SSchool x ExRace & 0.09 & 1 & 2.22 \\
\hline TGender $\mathrm{x}$ TRace $\mathrm{x}$ SGender $\mathrm{x}$ ExRace & 0.00 & 1 & 0.01 \\
\hline \multicolumn{4}{|l|}{ TGender x TRace x SSchool x SGender } \\
\hline $\mathrm{x}$ ExRace & 0.01 & 1 & 0.22 \\
\hline TGender $\mathrm{x}$ TRace $\mathrm{x}$ ExGender & 0.08 & 1 & 2.05 \\
\hline TGender $\mathrm{x}$ TRace $\mathrm{x}$ SSchool $\mathrm{x}$ ExGender & 0.14 & 1 & 3.51 \\
\hline TGender $x$ TRace $x$ SGender $x$ ExGender & 0.09 & 1 & 2.38 \\
\hline \multicolumn{4}{|l|}{ TGender $\times$ TRace $x$ SSchool $x$ SGender } \\
\hline ExGender & 0.05 & 1 & 1.17 \\
\hline TGender $x$ TRace $x$ ExRace $x$ ExGender & 0.04 & 1 & 0.99 \\
\hline \multicolumn{4}{|l|}{ TGender x TRace x SSchool x ExRace } \\
\hline \multicolumn{4}{|l|}{ TGender $\mathrm{x}$ TRace $\mathrm{x}$ SGender $\mathrm{x}$ ExRace } \\
\hline x ExGender & 0.15 & 1 & 3.81 \\
\hline \multicolumn{4}{|l|}{ TGender $\times$ TRace $\times$ SSchool x SGender } \\
\hline x ExRace x ExGender & 0.08 & 1 & 2.07 \\
\hline ERROR (TGender x TRace) & 0.396 & 224 & -- \\
\hline
\end{tabular}

${ }^{*} \mathrm{p}<.001($ following a significant Multivariate $\overline{\mathrm{F}})$

${ }^{* *} \mathrm{p}<.0001$ (following a significant Multivariate F) 


\section{Appendix $\mathbf{H}$}

ANOVA Summary on Personality as a Topic of

Self-Disclosure by Subject College, Subject Gender,

Examiner Gender, Examiner Race, Target Gender and Target Race

\begin{tabular}{lccc}
\hline Source & & \\
Between Subjects_Effects & 2.48 & 1 & 1.22 \\
SSchool & 0.01 & 1 & 0.05 \\
SGender & 12.01 & 1 & 5.88 \\
SSchool x SGender & 1.59 & 1 & 0.78 \\
ExRace & 0.06 & 1 & 0.03 \\
SSchool x ExRace & 1.83 & 1 & 0.90 \\
SGender x ExRace & 1.78 & 1 & 0.87 \\
SSchool x SGender x ExRace & 6.71 & 1 & 3.28 \\
ExGender & 1.54 & 1 & 0.75 \\
SSchool x ExGender & 4.70 & 1 & 2.30 \\
SGender x ExGender & 9.32 & 1 & 4.57 \\
SSchool x SGender x ExGender & 0.00 & 1 & 0.00 \\
ExRace x ExGender & 3.93 & 1 & 1.93 \\
SSchool x ExRace x ExGender & 5.72 & 1 & 2.80 \\
SGender x ExRace x ExGender & 0.70 & 224 & 0.34 \\
SSchool x SGender x ExRace x ExGender & 0.00 & & - \\
ERROR & & &
\end{tabular}

Within Subject Effects

Involving Target Gender

TGender

5.44

TGender $x$ SSchool

0.09

TGender $x$ SGender

0.52

TGender $x$ SSchool $x$ SGender $\quad 0.03$

TGender $x$ ExRace

0.05

TGender $x$ SSchool $x$ ExRace

0.05

TGender $x$ SGender $x$ ExRace

1.00

TGender $x$ SSchool $x$ SGender $x$ ExRace

0.61

TGender $x$ ExGender

0.12

TGender $x$ SSchool $x$ ExGender

0.22

TGender $x$ SGender $x$ ExGender

0.18

TGender $x$ SSchool $x$ SGender $x$ ExGender

0.03

TGender $x$ ExRace $x$ ExGender

0.07

TGender $x$ SSchool $x$ ExRace $x$ ExGender

0.00

TGender $x$ SGender $x$ ExRace $x$ ExGender

0.03

$25.59 * *$

0.43

2.45

0.16

0.25

0.22

4.68

2.85

0.59

1.03

0.83

0.15

0.33

0.00

TGender $x$ SSchool $x$ SGender $x$ ExRace $x$ ExGender

ERROR (TGender)

0.20

0.213

0.13

1

0.94

224 
Within Subject Effects

Involving Target Race

TRace

87.84

0.37

0.19

TRace $x$ SGender

0.18

0.63

0.00

3.62

0.15

0.10

0.14

0.11

1.13

5.10

1.56

0.14

1.16

0.447

$x$ ExGender

ERROR (TRace)

Within Subject Effects

Involving Target Gender x Target Race

TGender $x$ TRace

TGender $x$ TRace $x$ SSchool

TGender $x$ TRace $x$ SGender

TGender $x$ TRace $x$ SSchool $x$ SGender

TGender $x$ TRace $x$ ExRace

TGender $x$ TRace $x$ SSchool $x$ ExRace

TGender $x$ TRace $x$ SGender $x$ ExRace

TGender $x$ TRace $x$ SSchool $x$ SGender $x$ ExRace

TGender $x$ TRace $x$ ExGender

TGender $x$ TRace $x$ SSchool $x$ ExGender

TGender $x$ TRace $x$ SGender $x$ ExGender

TGender $x$ TRace $x$ SSchool $x$ SGender ExGender

TGender $x$ TRace $x$ ExRace $x$ ExGender

TGender $x$ TRace $x$ SSchool $x$ ExRace $x$ ExGender

TGender $x$ TRace $x$ SGender $x$ ExRace $x$ ExGender

TGender $x$ TRace $x$ SSchool $x$ SGender $x$ ExRace $x$ ExGender

ERROR (TGender $x$ TRace)
0.05

0.21

0.07

3.10

0.22

0.22

0.10

0.21

0.00

0.28

0.02

0.00

0.04

0.06

0.11

0.01

0.059
$196.45 * *$

0.83

0.43

0.40

1.40

0.01

8.11

0.33

0.22

0.33

0.24

2.53

11.41

3.50

0.31

2.59

224

-

0.87

3.60

1.16

1.65

3.67

3.76

1.67

3.56

0.01

4.67

0.35

0.03

0.65

1.06

1.87

0.21

224

${ }^{*} \mathrm{p}<.001$ (following a significant Multivariate $\mathrm{F}$ )

${ }^{* *} \mathrm{p}<.0001$ (following a significant Multivariate F) 


\section{APPENDIX I}

ANOVA Summary on Body as a Topic of

Self-Disclosure by Subject College, Subject Gender, Examiner Gender, Examiner Race, Target Gender and Target Race

Source

\section{Between Subjects Effects}

SSchool

SGender

SSchool x SGender

ExRace

SSchool $x$ ExRace

SGender $x$ ExRace

SSchool x SGender $x$ ExRace

ExGender

SSchool x ExGender

SGender $x$ ExGender

SSchool $x$ SGender $x$ ExGender

ExRace $x$ ExGender

SSchool $x$ ExRace $x$ ExGender

SGender $x$ ExRace $x$ ExGender

SSchool $x$ SGender $x$ ExRace $x$ ExGender

ERROR

Within Subject Effects

Involving Target Gender

TGender

TGender x SSchool

TGender $x$ SGender

TGender $x$ SSchool $x$ SGender

TGender $x$ ExRace

TGender $x$ SSchool $x$ ExRace

TGender $x$ SGender $x$ ExRace

TGender $x$ SSchool $x$ SGender $x$ ExRace

TGender $x$ ExGender

TGender $x$ SSchool $x$ ExGender

TGender $x$ SGender $x$ ExGender

TGender $x$ SSchool x SGender $x$ ExGender

TGender $x$ ExRace $x$ ExGender

TGender $x$ SSchool $x$ ExRace $x$ ExGender

TGender $x$ SGender $x$ ExRace $x$ ExGender

TGender $x$ SSchool $x$ SGender $x$ ExRace

$$
x \text { ExGender }
$$

ERROR (TGender)
15.36

0.09

6.35
2.31

2.29

1.13

2.28

0.24

0.02

1.59

5.91

2.89

0.00

3.32

3.90

9.92

2.93

2.789

5.03

0.13

1.27

0.00

1.83

0.98

0.65

0.05

0.55

0.27

0.03

0.38

0.01

0.03

0.242
2.28

0.83

0.82

0.41

0.89

0.09

0.01

0.57

2.12

1.04

0.00

1.19

1.40

3.56

1.05

- -

$63.38 * *$

0.08

$20.77 * *$

0.54

5.26

0.01

7.55

4.06

2.69

0.20

2.28

1.13

0.16

1.56

0.03

0.13 


\begin{tabular}{|c|c|c|c|}
\hline Source & Mean Square & $\mathrm{df}$ & $\mathrm{F}$ \\
\hline \multicolumn{4}{|l|}{ Within Subject Effects } \\
\hline \multicolumn{4}{|l|}{ Involving Target Race } \\
\hline TRace & 59.43 & 1 & $130.74 * *$ \\
\hline TRace x SSchool & 0.57 & 1 & 1.26 \\
\hline TRace x SGender & 0.01 & 1 & 0.02 \\
\hline TRace x SSchool x SGender & 0.14 & 1 & 0.31 \\
\hline TRace $x$ ExRace & 0.23 & 1 & 0.51 \\
\hline TRace x SSchool x ExRace & 0.15 & 1 & 0.34 \\
\hline TRace x SGender x ExRace & 2.67 & 1 & 5.87 \\
\hline TRace x SSchool x SGender x ExRace & 0.01 & 1 & 0.02 \\
\hline TRace x ExGender & 0.28 & 1 & 0.61 \\
\hline TRace x SSchool x ExGender & 0.00 & 1 & 0.01 \\
\hline TRace x SGender x ExGender & 0.04 & 1 & 0.97 \\
\hline TRace X SSchool x SGender x ExGender & 0.44 & 1 & 0.97 \\
\hline TRace x ExRace x ExGender & 6.29 & 1 & 13.83 \\
\hline TRace x SSchool x ExRace x ExGender & 0.77 & 1 & 1.70 \\
\hline TRace x SGender x ExRace x ExGender & 0.02 & 1 & 0.05 \\
\hline \multicolumn{4}{|l|}{ TRace x SSchool x SGender x ExRace } \\
\hline $\mathrm{x}$ ExGender & 0.59 & 1 & 1.30 \\
\hline ERROR (TRace) & 0.455 & 224 & -- \\
\hline \multicolumn{4}{|l|}{ Within Subject Effects } \\
\hline \multicolumn{4}{|l|}{ Involving Target Gender $\times$ Target Race } \\
\hline TGender $\mathrm{x}$ TRace & 0.75 & 1 & 12.86 \\
\hline TGender $x$ TRace $\times$ SSchool & 0.30 & 1 & 5.08 \\
\hline TGender $\mathrm{x}$ TRace $\mathrm{x}$ SGender & 0.11 & 1 & 1.93 \\
\hline TGender $x$ TRace $x$ SSchool x SGender & 0.05 & 1 & 0.82 \\
\hline TGender $\mathrm{x}$ TRace $\mathrm{x}$ ExRace & 0.00 & 1 & 0.02 \\
\hline TGender $\mathrm{x}$ TRace $\mathrm{x}$ SSchool x ExRace & 0.07 & 1 & 1.22 \\
\hline TGender $x$ TRace $x$ SGender $x$ ExRace & 0.00 & 1 & 0.02 \\
\hline \multicolumn{4}{|l|}{ TGender $\times$ TRace $\times$ SSchool $x$ SGender } \\
\hline $\mathrm{x}$ ExRace & 0.01 & 1 & 0.16 \\
\hline TGender $\mathrm{x}$ TRace $\mathrm{x}$ ExGender & 0.00 & 1 & 0.05 \\
\hline TGender $\mathrm{x}$ TRace $\mathrm{x}$ SSchool $\mathrm{x}$ ExGender & 0.01 & 1 & 0.21 \\
\hline TGender $x$ TRace $x$ SGender $x$ ExGender & 0.10 & 1 & 1.71 \\
\hline \multicolumn{4}{|l|}{ TGender x TRace x SSchool x SGender } \\
\hline ExGender & 0.02 & 1 & 0.38 \\
\hline TGender $x$ TRace $x$ ExRace $x$ ExGender & 0.09 & 1 & 1.51 \\
\hline \multicolumn{4}{|l|}{ TGender $x$ TRace $x$ SSchool $x$ ExRace } \\
\hline x ExGender & 0.02 & 1 & 0.27 \\
\hline \multicolumn{4}{|l|}{ TGender $x$ TRace $x$ SGender $x$ ExRace } \\
\hline x ExGender & 0.03 & 1 & 0.49 \\
\hline \multicolumn{4}{|l|}{ TGender $x$ TRace $x$ SSchool $x$ SGender } \\
\hline x ExRace x ExGender & 0.03 & 1 & 0.56 \\
\hline ERROR (TGender x TRace) & 0.058 & 224 & - \\
\hline
\end{tabular}

${ }^{*} \mathrm{p}<.001$ (following a significant Multivariate $F$ )

$* *_{p}<.0001$ (following a significant Multivariate F) 


\section{BIBLIOGRAPHY}

Backner, B.L. (1970). Counseling Black students: Any place for Whitey? Journal of Higher Education, 41, pp. 630-637.

Briley, C.E. (1977). The relationship between race, sex, type of problem and interpersonal trust in determining ethnic-racial preference for counselor. Dissertation Abstracts International, 38, 3282-A.

Brooks, L. Interactive Effects of Sex and Status on Self-Disclosure, Journal of Counseling Psychology, 1974, 21, pp. 469-474.

Casciani, J.M. Influence of Model's Race and Sex on Interviewees' SelfDisclosure, Journal of Counseling Psychology, 1978, Volume 25, №. 5 , pp. $435-440$.

Chaikin, A.L. \& Derlega, V.J. (1974). Self-disclosure. Morristown, N.J.: General Learning Press.

Cimbolic, P.T. (1972). Counselor race and experience effects on Black clients. Journal of Consulting and Clinical Psychology, 39, pp. 328332.

Cimbolic, P.T. (1973). T Group effects on Black clients' perceptions of counselors. Journal of College Student Personnel, 14, pp. 296-302.

Cosby, S.G. Race, Gender, and Socioeconomic Status, and Self-Disclosure, unpublished manuscript, University of Rhode Island, 1983.

Cozby, P. Self-Disclosure: A Literature Review, Psychological Bulletin, 79 (February 1973), p. 80.

Derlega, V.J. and Berg, J. (1987). Self-Disclosure, Theory, Research, and Therapy. New York: Plenum Press.

Dimond, R.E. and Hellhamp, D.T. Race, Sex, Ordinal Position of Birth, and Self-Disclosure in High School Students, Psychological Reports, 1969, 25, pp. $235-238$. 
Ewing, T.M. (1974). Racial similarity of client and counselor and client satisfaction with counseling. Journal of Counseling Psychology, 21, pp. 446-449.

Fleming, J. "Fear of Success, Achievement-Related Motives and Behavior in Black College Women." Journal of Personality, 1978, 46, pp. 694-716.

Fleming, J. Impact of Predominantly White and Predominantly Black College Environments on Black Students. Unpublished technical report, United Negro College Fund, September 1980.

Fleming, J. "Sex Differences in the Impact of College Environments on Black Students." In P.J. Perun (ed.), The Undergraduate Woman: Issues in Educational Equity. Lexington, Massachusetts: Lexington Books, $1982 \mathrm{~b}$.

Fleming, J. Black Women in Black and White College Environments: The Making of a Matriarch, Journal of Social Issues, Vol. 39, No. 3, 1983, pp. 41-54.

Fleming, J. Blacks in College, San Francisco: Jossey-Bass Publishers, 1984. Franco, J.N., Malloy, T., and Gonzalez, R. Ethnic and Acculturation Differences in Self-Disclosure, The Journal of Social Psychology, 1984, 122, pp. 21-32.

Gamboa, A.M., Tosi, D.J., and Riccio, A.C. (1976). Race and counselor climate in the counselor preference of delinquent girls. Journal of Counseling Psychology, 23, pp. 160-162.

Gibbs, J.T. "Black Students/White University: Different Expectations." Personnel and Guidance Journal, 1973, 51, pp. 463-469.

Gibbs, J.T. (1975). Use of mental health services by Black students at a predominantly White university: A three year study. American Journal of Orthopsychiatry, 45 , pp. 430-445.

Griffith, M.S. (1977). The influences of race on the therapeutic relationship. Psychiatry, 40, pp. 27-40. 
Hill, C.T., Peplau, L.A. \& Rubin, Z. (1981). Differing perceptions in dating couples: Sex roles versus alternative explanations. Psychology of Women Quarterly, 5, 418-434.

Hill, C.T., Rubin, Z. and Peplau, L.A. (1976). Breakups before marriage: The end of 103 affairs. Journal of Social Issues, 32(1), 147-168.

Himmelstein, P. and Lubin, B. Attempted Validation of the Self-Disclosure Inventory by the Peer-Nomination Technique. Journal of Counseling Psychology, 1965, 61, pp. 13-16.

Horney, K. Neurosis and Human Growth, W.W. Norton and Company, 1950. Inman, D.J. (1978). Self-disclosure and interview reciprocity (Doctoral dissertation, Louisiana State University \& Agriculture \& Mining College, 1978). Dissertation Abstracts International, 38, 3398B.

Jackson, G.G. and Kirschner, S.A. Racial Self-Designation and Preference for a Counselor, Journal of Counseling Psychology, 1973, 20, pp. 560-564. Jackson, J. (1975). Black college students' preferences of Black and White counselors in a White university. Dissertation Abstracts International, $\underline{36}, 5824 \mathrm{a}$.

Jourard, S.M. The Transparent Self, New York: Van Nostrand Reinhold, 1968. Jourard, S.M. Self-Disclosure: An Experimental Analysis of the Transparent Self, New York: Wiley Interscience, 1971.

Jourard, S.M. and Laskow, P. Some Factors in Self-Disclosure, Journal of Abnormal and Social Psychology, 1958, 56, pp. 91-98.

Jourard, S.M. Disclosing Man to Himself. D. Van Nostrand Company, 1968.

Keppel, G. Design and Analysis: A Researcher's Handbook, Prentice Hall, Inc., 1982 .

Komarovsky, M. (1974). Patterns of self-disclosure of male undergraduates. Journal of Marriage and the Family, 36, 677-686.

Littlefield, R.P. "Self-Disclosure Among Some Negro, White, and MexicanAmerican Adolescents," Journal of Counseling Psychology, 1974, 21, pp. 133-136. 
Mays, Benjamin E.. Born to Rebel: An Autobiography, New York: Scribner, 1971 ,

Olive, J.D. and Clark, V.A. Applied Statistics: Analysis of Variance and

Regression: John Wiley \& Sons, 1987.

Panyard, C.M. "Self-Disclosure Between Friends: A Validity Study." Journal of Counseling Psychology, 1973, 20, pp. 66-68.

Parham, T.A. and Helms, J.E. "The Influence of Black Students Racial Identity Attitudes on Preferences for Counselors Race." Journal of Counseling Psychology, 1981, 28, pp. 250-257.

Pedersen, D.M. and Breglio, V.J. "Personality Correlates of Actual Self-

Disclosure, Psychological Report, 1968, 22, pp. 495-501.

Pederson, D.M. and Higbee, K.L. "An Evaluation of the Equivalence and

Construct Validity of Various Measures of Self-Disclosure."

Educational and Psychological Measurement, 1968, 28, pp. 511-523.

Pinchot, N., Riccio, A.C. and Peters, H.J. (1975). "Elementary school

students' and their parents' preferences for counselors." Counselor Education and Supervision, 15, pp. 28-33.

Riccio, A.C. and Barnes, K.D. (1973). Counselor preferences of senior high school students. Counselor Education and Supervision, 13, pp. 36-40.

Rubin, Z. (1976). Naturalistic studies of self-disclosure. Personality and Social Psychology Bulletin, 2, 260-263.

Rubin, Z. and Shenker, S. (1978). Friendship, proximity, and self-disclosure. Journal of Personality, 46, 1-11.

Rubin, Z., Hill, C.T., Peplau, L.A. and Dunkel-Schetter, C. (1980). Selfdisclosure in dating couples: Sex roles and the ethnic of openness. Journal of Marriage and the Family, 42, 305-317.

Singleton, D.E. Racial self-designation, self-disclosure, and counselor preference, unpublished manuscript, George Washington University, 1976. 
Stranges, R. and Riccio A. (1970). Counselee preference for counselors:

Some implications for counselor education. Counselor Education and Supervision, 10, pp. 39-46.

Thompson, Daniel C. "Black College Faculty and Students: The Nature of Their Interaction". Black Colleges in America: Charles V. Willie and Ronald R. Edmonds, eds., Teachers College Press, 1978.

Thompson, R.A. and Cimbolic, P. (1978). Black students' counselor preference and attitudes toward counseling center use. Journal of Counseling Psychology, 25, pp. 570-575.

Vontress, C.F. Cultural barriers in the counseling relationship. Personnel of Counseling Psychology, 1974, Volume 21, No. 6, pp. 522-525.

Willie, C.V. and Edmonds, R.R. (eds.) Black Colleges in America. New York: Teachers College Press, 1978.

Wolkon, G.H., Moriwaki, S., and Williams, K.J. Race and Social Class as Factors in the Orientation Towards Psychotherapy. Journal of Counseling Psychology, 1973, 20, pp. 312-316.

Zeedyk-Ryan, J., Carman, R.S. and Fitzgerald, B.J. The recipient of selfdisclosure. Journal of Psychology, 1981, 109, pp. 123-125. 